Portland State University

PDXScholar

\title{
The historical imagination of Francesco Petrarch: a study of poetic truth and historical distortion
}

Sally Scholz

Portland State University

Follow this and additional works at: https://pdxscholar.library.pdx.edu/open_access_etds

Part of the Cultural History Commons, Intellectual History Commons, and the Other Italian Language and Literature Commons

Let us know how access to this document benefits you.

\section{Recommended Citation}

Scholz, Sally, "The historical imagination of Francesco Petrarch: a study of poetic truth and historical distortion" (1974). Dissertations and Theses. Paper 2143.

https://doi.org/10.15760/etd.2141

This Thesis is brought to you for free and open access. It has been accepted for inclusion in Dissertations and Theses by an authorized administrator of PDXScholar. Please contact us if we can make this document more accessible: pdxscholar@pdx.edu. 
AN ABSTRACT OF THE THESIS OF SAlly Scholz for the Master of Ares in History presented August 9,1974 .

Titie: The Historical Imagination of Francesco Petrarch: A Study of Poetla Truth and Historicai Distortion.

APPROVED BY MEMBERS OF THE THESIS COMMTTEE:

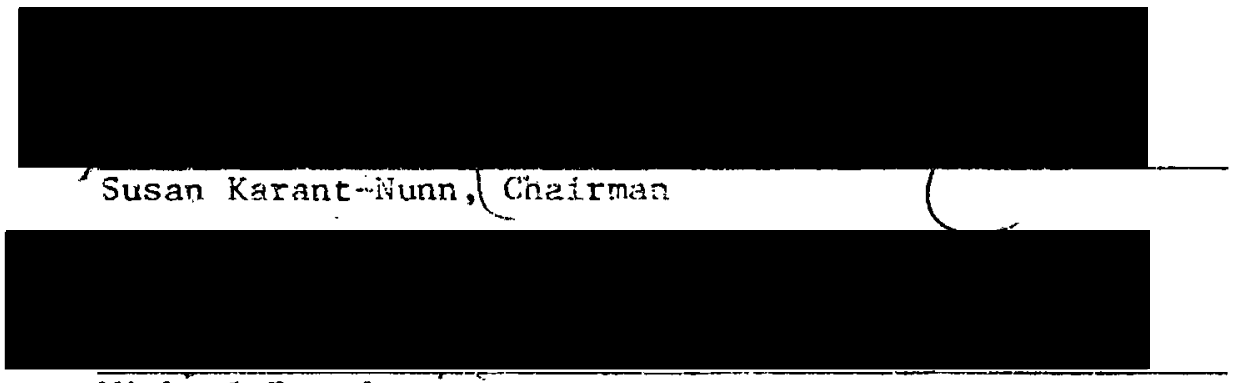

Michae1 Reardon

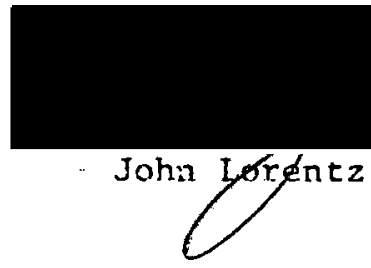

In the continuing debate among bistortans over the nature, if not the actual. existepce, of the Italian Renaissance, the life of Francesco Petzarch has played a major role. Petrerch was an outspoken critic and commentator on the state of fourteenth-century soclety. HAs oplnions have been cited by all scholats interested In the ortgins of the "Renaissance atind."

The concern of this paper will be to discuss the sources, development, and purpose of Petrarch's historlcal imagination. By tracing the course of Petrarch's 1ife I have tried to expose the 
the varlous factors bearing on his psychological development. His "exile" from Italy, early schooling in. France and Italy, and political and literary associations provide us with the background. Analysis of Petrarch's literary creations--the books and letters--allow us to see his historical imagination in action.

There are two major methodological problems that the critic must face in this study. This first is that of translations. The English transzations of Petrarch's letters and books also must face the proslem of distortion of specific words. The letters have also been collected in a manner which reinforces the traditional view of Petrarch as the first humanist. There is a built-in bias toward the ideas earlfer generations found most germane to the MedievalRenaissance distinction.

A second major problem is that of chronology. A11 of Petrarch's letters, the Africa, The Lives of Illustrious Men, The Secret, the Life of Solitude, and the Triumphs are avallable only in thetr final form, endorsed by Petrarch after years of insertions and revision. It Is impossible to do a strict evolutionary or linguistic study because the earlier versions are not avallable. On a general level, however, we can perceive conceptual changes in Petrarch's historical tmaglnation. By using information on dates and insertions, we can observe which subjects were most important at different times in Petrarch's 1ife.

It is my thesis that Petrarch's view of history was essentially romantic. Petrarch used facts and a crftical methodology to bolster 
an ideal. The re-creation of the Roman splrtt in fourteenth-century culture was his goal. Petrarch thus felt jugtified in remodeling historical facts to serve as examples to his contemporaries. In the "Invective Against a Man spoke III of Italy" witten a year before Petrarch's death, he asks "What is all History but Praise of Rome?" I will take this as the quinteasential statement of the function of Petrarch's historical imagination. The key word is "pralse" for it reveals the pervasive historical romanticism with which Petrarch approached his subject.

The phrase "histortcal Imagination" does not necessartiy imply a romantic vision. Practical solutions can be offered if the world Is seen reallstleally as well as lmaglnatively. Petrarch, however, Identified so completely with his ideal of Roue that concrete applications of Roman precedents to fourteenth-century Italy escaped him. As is evidenced in his works and deeds, fron Afrlca and the Coronation to Cola and Charles IV, the appearance of a classical manner was all Iuportant.

Patrarch was both a historian and a poet. His goal was the resurrection of Roman virtue in Irecento society. It was to this end that be incorporated historlcal facts into his poetic sensibility. Petrarch used his historical Imagination as a neans of bridging the gap between the real and the Ideal in hope of seeing Rone rise agaln. 
THE HISTORICAL TRAGINATION OF FRANCESCO PETRARCH: A STUDY OF POETIC TRUTH AND HISTORICAL DISTORTION

by

SALLY SCHOLZ

A thesis submitted in partial fulfillment of the requirements for the degree of

MASTER OF ARTS

in

HISTORY

Portland State University

1974 
TO THE OFFICE OT GRADUATE STUDIES AND RESEARCE:

The members of the comittee approve the thesis of

Sally Scholz presented August. 9, 1974.

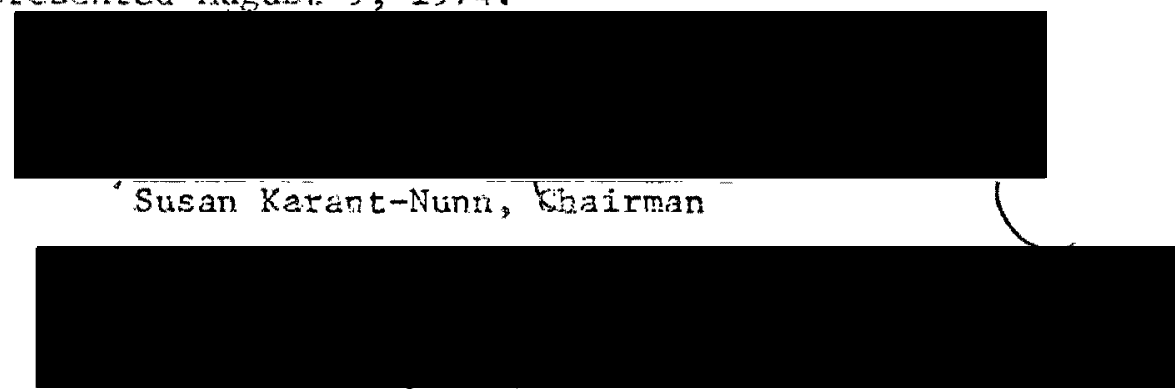

Michae1 Rezrdon

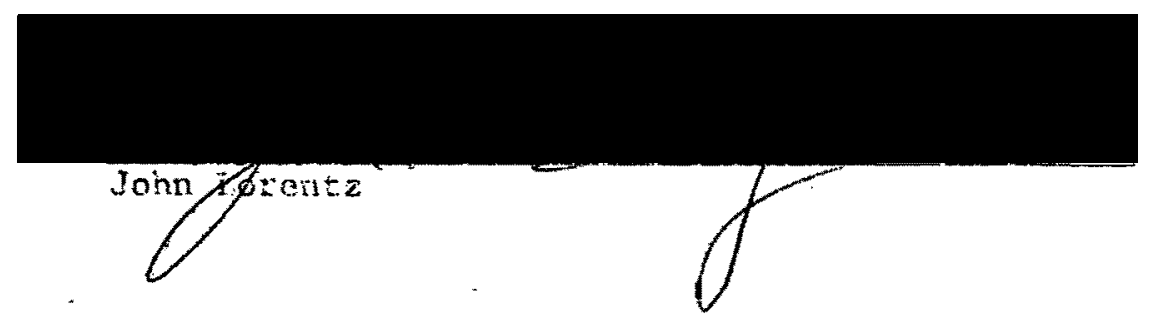

APPROVFD:

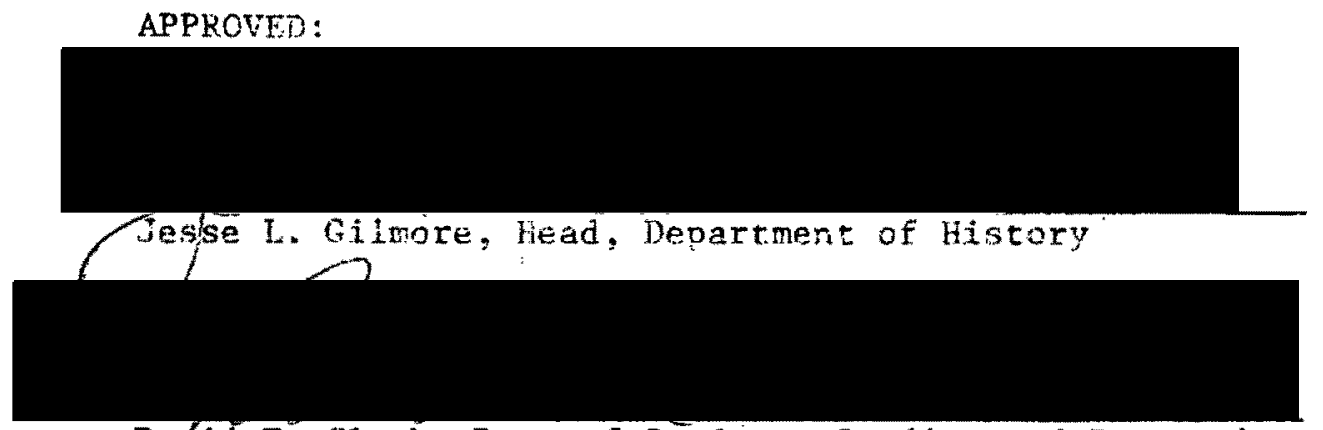

Dabid T. Clark, Desn of Graduate Studies and Research 
TABLE OF CONTENTS

CHAPTER

PAGE

I INTRODUCTION

1

II A CHRONOLOGICAL STUDY OF THE EVOLUTION

12

III CONCLUSION

77

BIBLIOGRAPHX

88 
CHAPTER I

\section{INTRODUCTION}

In the continuing debate among historians over the nature, if not the actual existence, of the Italian Renalssance, the life of Francesco Petrarch has played a major role. Petrarch was an outspoken critic and comentator on the state of fourteenth century society. His oplaions have been cited by all seholars interested hn the origins of the "Renaissance Mind." Through the distortion of hinisight, Petrarch can be portrayed as the self-conscious "humanist" who literally "climbed Mont Ventoux in order to open the Renaiasance." 1 Scholars have also made Petrarch a cultural half-breed by taking con tradictory statements out of context and setting then against one another. Petrarch 1s then trapped with one foot in the dark age and one in the light so that he "didn't foresee the modern world which began with himself." 2

This seeming necessity to conceptualize the flow of the into watertight categories of "Medieval" and "Renalssance" has disconnected the historical Petrarch from the Trecento, He is not allowed to exist in the chaotic movement of his own time but is held static between the waning of the Middle Ages and the dawn of the modern world. This

IQuentin-Sklaner, "Meaning and Understanding in the History of Ideas," History and Theory, VIII (1969), p. 23.

2John H. Whitfield, Petrarch and the Renascence Coxford: BaB11 Blackwe11, 1943), p. 41. 
blas defines Petrarch in terms of shat is expected of the preceding and succeeding ages. Petrarch's life is then important only in what 1t was not. What may have been a rhetorical device or an innocent statement becomes a revelation of a "medieval Augustinian conscience" or else of "proto-humanism." The statement that Petrarch "did not set himself the deliberate task of refuting in detail the learning of the Mddle Ages" begs the question. ${ }^{3}$ It relegates Petrarch to a position he could never have imagined. Petrarch did not have an ouniscient vision of what the future would bring. He did, however, hope for the "dawn of a new age." 4 In order to understand Petrarch's expectations, it is necessary to see how he used the past as a model.

The concern of this paper will be to discuss the sources, development, and purpose of Petrarch's historical 1maginacion. That posterity has seen Perrarch as the "first tourist," the "first mountalneer" (1.e. F. Gribble's Early Mountatneers), the "first Itallan patriot," and the "Father of Fumanism" tells us little about how he say himself. 5 This question can be answered only in the context of his Iife and works. Petrarch's psychological development is central to a definition of him as an historian. An analysis of Petrarch's 11terary creations will allow us to see the external manifestations of his historical method and imagination.

3ibid., p. 47.

${ }^{4}$ Morris Bishop, Petrarch and His World (London: Chatto and Windus, 1964), p. 179 .

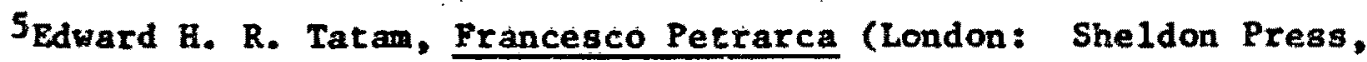
1926), p. 302 . 
It is my thesis that Petrarch's view of history was essentially romantic. Petrarch used facts and a critical wethodology to bolster an 1deal. The re-creation of the Roman spirit in fourteenth-century culture was his goal. Petrarch this felt justifled in remodeling historical facts to serve as examples to his contemporaries.

Petraxch's view of Rowan history was no more romantic than his perception of his own times. In his relation to both the past and the present, Petrarch used history imaginatively. He was not a social reformer, however, because he preferred a life of scholarship to one of social action. Petrarch's Ideas about Trecento culture were distorted by his vision of antiquity. As a historian, therefore, Petrarch offered historically imposstble solutions.

We would do Petrarch an infustice by defining him as an historian without allowing him to be a poet as well. The term "historical imagination" is to be taken not in reference to the creative ability of a professional historian. Petrarch was, after all, a poet who saw history as subsumed in poetry. There can be little distinction between the historical fact and the poetic construct it bullt. The end result was not objective presentation of "truth." Petrarch's goal in writing both poetry and history was the rooral enlightenment of wen. The propagandistic role of both forms is primary. It is important that a proper distinction be established between a mere philosophical or poetic reflection of the mutability and transcience of all thinge in either a Christian or Lucretian spirit and a cyclical theory that is directly applicable to history. 6

${ }^{6}$ Frank E. Manual, Shapes of Phtlosophical History (Stanford: Stanford University Preas, 1965), P. 53 . 
Unfortunately, this is an Impossible task vith Petrarch. True poetry grew out of history. Petrarch would see no distinction between mere philosophic or poetic reflections and his historical work. Petrarch states in Africa,

The liberties enjoyed by the poet are not as great as most people like to believe. He must first anchor his work on the f1rmest: foundations of truth. Resting on these, he can conceal himself under a colorful and atrractive cloud, providing the reader with long and pleasing labor or a search which becomes more demanding the greater the truth, but which becomes sweeter once the truth is uncovered. Whatever, the labor of historians, whatever the cult of virtue and the lessons of life, whatever the study of nature, these are all rightful concerns of the poet, belleve me; provided, however, that these things are hidden by an unrecognized covering so that while they are clearly seen elsewhere, they now deceive the cyes by intermittently emerging from and returning to their place of hiding. Whoever invents whatever he writes deserves neither the name of poet nor the prestige of the prophet, but only the title of 11 ar. From this you can glean whatever you seek to know: the extent of our labor, the range of our interests, and the scope of our freedon. 7

Petrarch lived during a period of cultural transition. He stood between two ages of great contrast. It is not strange that Petrarch Is a victin of Medieval and Renaissance stereotypes. He asked for it by leaving such intriguing statements as "Pliny's History of the Romans disappeared in our own times. Our descendants will have no knowledge of the past. I an as if on the frontlers of two peoples, looking forward and backward." 8 whether through arrogance or insecurtty, Petrarch did have a strong sense of his potential value to history. The constant revision of his letters and other works hints at something

${ }^{7}$ Quoted by Aldo S. Bernardo in Petrarch, Sclplo and the Africa (Balelwore: John Hopkins Press, 1962), p. 43.

${ }^{8}$ Quoted by Bishop In Petrarch and H1s World, p. 99. 
beyond perfectionism. Petrarch did not write marely to made a name. He wanted to reveal only his best features. Hence, Petrarch misrepresented himself by revising early letters to fit his conception of a wature personality. This does not tell us that Petrarch foresaw the coming cultural revival and structured his appearance to sut it. The need for ego-gratification is comon to men of all times. Petrarch was too well known and envied not to be slightly insecure.

Our knowledge of this constant revision leads to both methodological and interpretive problems. The tradirional school of Petrarci scholars sought and found consistency in this thought by ignoring its evolution. 9 James Harvey Robinson's Petrarch: The First Modern Scholar and Man of Letters is typical of this outlook. Subtitled "a selection from the correspondence with Boccaccio and other friends, designed to illustrate the beginnings of the Renalssance," the book is organized around a topical rather than a chronological scheme. The chapters entitled "The Father of Humanism" and "Political Opinions" $m 1 x$ letters and miscellaneous statements of Petrarch's youth and old age. In this way Robinson can "prove" almost anything he wants. No change in Petrarch's outlook is allowed because chronology is 1gnored. Thomas Bergin, another advocate of the "systematic Petrarch," states,

${ }^{9}$ For English works of this group see Plerre de Nolhac's Petrarch and the Ancient World (Boston, 1907); Mario Emilio Cosenza's Francesco Petrarch and tina Revolution of Cola de Rienzo (Ch1cago, 1913); Tatam's Francesco Petrarca; Theodore E. Mommens" "Petrarch's Conception of the Dark Ages" Speculum, 1942); Whitfield's Petrarch and the Renascence; and Tnomas G. Bergin's Petrarch (New York, 1970). 
one cannot speak truly of developrent in Petrarch; one wust

take his works en bloc; there is not a Fetrarch of the Canzoniere and a Petrarch of. the Afrdca, so far as any chronological criterion is concerned, to

Petrarch's 11 fe and work have been totally distorted by this assumption of a perfectly ordered system. Consistency seems to be required of all cultural heroes. Anything that does not fit the pattern of coherence is excused as a mental lapse. It is this attitude which led Tatam to call one of Petrarch's most 1yrical and sensitive later works, the Triunph of Ecernity, a "gradual reversion to the medleval standpoint."1l According to Tatam, Petrarch did not gros out of the Midde Ages and Into the Renaissance in good chronological order. Petrarch destroyed Tatam's convenient system by responding to the fears, threats, and disappointments which characterized his old age.

The recent work of Carlo Calcaterra, Guldo Martellott1, Giuseppe Billanovich, Hans Baron, and Ernest Hatch Hilkins provides an evolutionary interpretation of Petrarch's writing. 12 For them consistency is not a prerequisite to virtue. Carlo Calcaterra's study of the "Secretur crists," Petrarch's rellglous "conversion" of 1342-43, has

10 Thomas G. Bergin, Petrarch (New York: Twayne Publishers, Inc., 1970), F. 38 .

11 Tatam, Francesco Petrarca, p. 118.

12 See Carlo Calcaterra Nella Selva del Petrarca (Rome, 1942); Guldo Marteliotri "IInee di soiluppo dell 'unamesimo petraresco," Studi Petrarcheschi, II (1949); Giuseppe Billanovich "Nella Biblioteca delPetrarca," Italla Medicevale e Unantstica, III (1960); Hans Baron "The Evolution of Petrarch's Thought: Reflactions on the state of Petrarch Studies," From Petrarch to Brumi: Studtes in Humanistic and Political Literature (Chicago, 1968); and Ernest Hatch Wilkins The Life of Petrarch (Chicago, 1961). 
led to a reappraisal of the early letters. What was once seen as youthful melancholy now becomes a revelation of Petrarch's religiosity. By revising parts of his letters, Petrarch stucceeded in confusing generations of scholars.

Theodore Mommen credited Petrarch with periodizing history Into ages of 1ight and dark. Petrarch thus becomes the first "modern" historian to acknowledge the existence of the Middle Ages. Unfortunately, Motrmsen's evidence came from an incorrectly dated version of The Lives of Illustrious Men (De Viris Illustribus). Mommen worked from an early version of the work which included only Roman heroes. This is why he believed that Petrarch had excluded Medieval Christians on princtple. The age of darkness was taken as specific reference to what later humanists would see as medieval. Guido Martellott 1 has shown that the final version of The Lives included both Roman and Medieval figures. After his religlous introspection in the $1340^{\prime} \mathrm{s}$, Petrarch was able to use men of both periods as models. In other words, Petrarch's historical imagination had already expanded beyond Mowmen's finely drawn boundaries.

The textual exegesis of Giuseppe Bilianovich has proved that Petrazch's climb of Mont Ventoux in 1336 has little to do with the falsely dated letter of 1352-53.13 This letter reflects Petrarch's thoughts ten years after the "Secretum crials." The "Ascent of Mont

${ }_{13}$ Giuseppe B11lanovlch, Petrarca Letterato (Rome, 1947), quoted by Bans Baron in "The Evolution of Petrarch's Thought," p. 18. 
Ventoux" symbolizes a spirltual state rather than an actual mountain climb. BIllanovich has uncovered Petrazch's artempt to cover his youthful optinism with a more "appropriate" religlous concern.

Emest Hatch Wilkins, the suprene American Fetrarchist, provided the most detailed and convincing studies of Petrarch's 11 fe and work. In his three biographies, Wilkins recreated Petrarch's 11fe by depending solely on the extant letters and books. ${ }^{14}$ Because W11kins spent years on a minute study of the dates of Petrarch's work, he could decide what the wily suthor had Inserted at a later time. The information supplied by this new approach proves the absurdlty of seeking any one "key" to Petrarch's personallty.

Petrarch is now finally able to live his inconsistent life without fear of criticism for not reaching "modern" expectations. Hans Bazon says of the "Ascent of Mont Ventoux,"

The Increasing discovery of classical models for the phrases and 1iterary motifs in Petrarch's letter does not in itself throw any doubt on Petrarch's truthfulness. To make the language and the expressions of recognized literary mode1s one's own and to clothe experiences from one's own 11 fe in an inherited guise is the very heart of the humanistc program of rhetorlcal culture. To some extent, our judgment of how far Petrarch may have gone in outright deception while Invoking God and everything sacred to him as witness does not depend on what we regard as proper and usual in rhetorically minded authors, but on our total vision of Petrarch's personallty and piety. It is therefore bound up with the future development of our views of Petrarch. 15

14Ernest Hatch Wilkins, The LIfe of Petrarch; Petrarch's Eight Tears In Milan (Cambridge, Mass.: The Medieval Academy of America, 1958): Petrarch's Later Years (Cambridge, Mass.: The Hedieval Academy of Aserica, 1959).

15Baron, "The Evolution of Petrarch's Thought," p. 19. 
In discussing Petrarch's histortcal lagatnation I have tried to follow the wethodological guideliges set out by quentin Skinner in his "Meaning and Understanding In the History of Ideas." Skinner polats out the phllosophical weaknesses of two comwon wethods of Intellectual infsory. I have already mentioned that taking a document out of context may lead to the "wythology of coherence."16 Another danger in viewing the text as autonomous is a concern with "timeless questfons. 17 In this way Petrarch, the "Father of Humanisa," can be forced to coment on topics which are relevant oly to a generation of historlans who hsve already lived through the Renalssance.

The second method discussed by Skinner 18 intellectual biography. Here the text is analyzed wh reference to 1 is political, econowic, and social aftuation. The problem lies in the assumption that there Is a causal connection between inceras expression and external factors. Moreover, as Skinner says,

The 'context' mistakenly gets treated as the determinant of what 18 sald. It needs rather to be treated as an ultimate framework for belping to decide what conventionally recognizable meanings, in a society of that kind, it might in principle have been possible for someone to have intended to comounicate. 18

Skinner advocates the critics entry into the linguistic context as the only solution. The rhetorical Intention of the author can be deternined only by studylng the language as it was used. Unfortunacely. this thesis is already on the other side of this fine 1ine. The P. 16.

165kiner, Wieaning and Understanding In the History of Ideas,"

$$
\begin{aligned}
& 17 \text { Ib1d., p. } \\
& 18_{\text {Ib1d.. }} \text { p. } 49 .
\end{aligned}
$$


English translations of Petrarch's letters and books not only must face the problem of distortion of specific words. The letters have also been collected in a manner which refnforces the tradicional view of Pecrarch as the first humanist. There is a built in blas toward the ldeas earlier generations found most germane to the Medieval-Renaissance distinction.

A second major problem for the critic is that of chronology. All of Petrarch's letters, the Africs, The Lives of Illustricus Men, The Secret, the Iffe of Solitude, and the Triunghs are avaliable only in their final form, endorsed by Fetrarch after years of insertions and revision. The darker moods of old age had colored all Petrarch's work but creates an interpretive problem mainly in the early letters and sonnets. 19 It is Impossible to do a strict evolutionary or IInguistic study because Africa and The Lives are given only in secondary sources and the other works only in translation. On a general level, however, we can perceive conceptual changes in Petrarch's historical imagination. By using Wilkins' information on dates and Insertions, we can observe'which subjects were most important at different times in Petrarch's $11 \mathrm{fe}$.

The greatest difficulty comes in discerning Petrarch's intention. Even a catalogue of words comon to the time cannot reveal the Inguistic assumptions behind a phrase. It is not only a problem of rhetoric in evergday conversation, but of "rhetoric" as the study and use of classical styie and quotations to add a spark to ethical 
imperatives. We know that Petrarch of ten quoted Clcero out of context to make a point. However, we cannot determine how Petrarch expected his reader to respond. It is even more difficult to envision the reader's actual response to the rhetorical model. Even if twentieth-century assumptions and expectations could be washed out, we could not use social context alone to "grasp the intended illocutionary force." 20

My dependence on translations and secondary sources will necessarily limit the scope of this paper. The discussion of Petrarch's psychological development will be both tenative and incomplete. I will attempt, however, to discern changes in Petrarch's historical imagination by placing him in the context of his life and work as it 18 known to me. A causal connection between events and actions, between words and deeds, is not to be assumed. At most, I can hint at contriburing factors.

\footnotetext{
p. 46.

${ }^{20}$ Skinner, "Meaning and Understanding in the History of Ideas,"
} 


\section{A CRRONOLOGICAL STUDY OF THE EVOLUTION OF PETRARCH'S HISTORICAL TMAGINATION}

Prancesco Petrarch was born 1n the small Itallas clty of Arezzo 1n 1304. Petrarch's father was a native Florentine extled with Dante and other White Guelphs in 1302. The politfcal trimph. of the Black Guelphs led to the rewoval of the notary's family to Avignon, the current seat of the Holy See. Many Italians, Including Petrarch; referred to this beventy year "visit" of the Popes as the "Babylontan Captivity." The new papal clty of Avlgnon, however, provided more security and Intellectual stimulation than any place in Italy.

The barontal warfare of the Colonns and Orsint families left Rowe in anarchy from the mid-ehirteenth century. Since 1240 the Popes had rarely resided in Rone. The soujourn in Lyons had shown that a Pope could continue his functions outside Italy. 21 The storay relationship of Bontface VIII and Phililp the Patr of France revealed the danger of dependence on any one prince. The city of Avignon formed an enclave in the Contat-Venaisain, near to but not within France. The Angevin rulers of Naples, the Popes" strongest Itallan allies, actually owned the city. 22 Avignon was ensured of rapld coumuntcacton

21 Daniel Waley; Lacer Medieval Europe (New York: Barnes and Noble, Inc., 1964), p. 116.

${ }^{22}$ Guillawe Mollat, The Podes at Avignon (London: Thomas Nelson and Sons, Led., 1963), P. XIX. 
wth Italy by land and sea routes. Its location also removed the Popes from the direct pressures of Prench and Italian enemies.

As the Popes' residence, Avignon became by default the spiritual and cultural center of the Christian world. European princes, prelates, diplomats, and men of letters flocked to Avignon to conduct the busitess of the Holy See. It was in the midst of this intra-European forum that Petrarch recelved his early education, doubtiess a different one than he would have enjoyed in a small Iralian republic. Petrarch took advantage of the intellectual assets of Avignoa in the forative period of his youth, yet from the beginning directed his wost virulent prose at the unlucky city.

Unholy Babylon, thou Hell on earth, thou sink of lufquity, thou cesspool of the world! There is nelther faith, nor charity, nor religlon, nor fear of God, nor shane, nor truth, nor hollness, albeit the residence 1 thin its walls of the supreme pontiff ahould have made of it a shrine and the very stronghold of religion: . - Of all the cities that I know. Its stench is the worst. What dishonor to see it suddenly becoire the capieal of the world, when it should be the least of all cities.23

Petrarch's contact with the papal library, a progressive literary circle, and the benefits of curial patronage provided the best educational possibilities avallable. He refused to acknowledge this real situation, however, preferring to condem the new "capital of the world" cn spiritual grounds. For ten centurfes Rome had been the head of the Church and Eapire. Fetrarch did not allow fourteenthcentury spiritual and political realities to influence the basis of his historical outlook.

23 Ibld., p. 252. 
There was mlituited opportunity for empioynent in Avignon to men with education. Petrarch's father provided the best education money could buy in the hope his son would becowe a lawyer. It was the classical authors, however, who entranced the young scholar. From my early youth when other boys were studying only in Prosper and Aesop, I gave myself wholly to Cicero, whether through natural symathy or at the suggestion of ny father, who always held that author in highest veneration and who would himself have atrained some high reputation if domestic cares had not occupied his noble intelligence. . . That love for Cicero increased day by day, and my father, anazed, encouraged my imature propenstey through paternal affection. And I, dodging no labor that might aid my purpose, breaking the . rind began to savor the taste of the fruit, and couldn't be restrained from study. 24

When Petrarch was twelve his father sent him off to siudy law at Montpelifer. From there he moved in 1320 to the University of Bologna, the greatest center of legal studies in Europe. Here Petrarch was first exposed to poems written in the 1iving speech of Tuscany, the "sweet new style" of Dante. 25 Petrarch carried with him to Italy the heritage of the 1yric poetry of Provencal and Languedoc. His earliest literary creations were lyric poems In Italian nodeled on French tradition and the "Dolce Stil Nuovo." It would not be long, however, before Petrarch condemed these poems as "trifles." Because of his exposure to classical poetry Petrarch denied that the vulgare possessed the necessary decorum and serlousness to deal with welghty matters.

${ }^{24}$ Quoted by Bishop in Petrarch and His World, p. 21, Seniles XVI, 1 (1374).

25wilkins, The Life of Petrarch, P. 7. 
Petrarch's early Interest in Latin Classics galned momentim durling his legal studies. The legal currfculum demanded reading of the Romar historians, furisto, and poets. The more Petrarch read of Roman law anc history the more disgusted he because with the concerns of contemporazy lawyers.

The greatest part of our legists, who care nothing for knowing about the origins of law and about the founders of jurisprudence. and have no other preoccuparion than to gain as much as they can from their profession and are content to learn whatever is written In the law about contracts, fudgments or wills, and tit never cccurs to them that the knowledge of arts and of origins, and of literature would be of the greatest practical use for their profession. 26

Petrarch yas fascinared with the spirit behind the 1aw, with Roman history rather than current application of Roman law. The mundane ortentation of the legal curriculum could only increase Petrarch's sense of distance from historical Rome. His interest in the origins of law led Petrarch into the study of history through 11terature and Jurisprudence.

Only a year away from receiving the doctorate of law, Petrarch abruptly abandoned his legal studies inmediately after his father's death in 1326. He returned to Avignon and resumed his reading of ancient history. During this period he first saw Laura. While she did not affect his historical sense, Laura did become the central figure of Petrarch's love poems on which his early reputation was based. There is no clear connection between Petracch and the Curla before 1330. The conflict between Pope John XII and Louls of Bavaria

${ }^{26}$ Quoted by Peter Burke in The Resalssance Sense of the Past (London: Edward Arnold, 1969), p. 33. 
for suprewacy in Italy and the debate with the Spiritual franciscans over poverty vere only two of the 135 ves occupylng the papacy in the $1320^{\prime} \mathrm{s}$. Petrarch was not involved in these disputes. Living off h1s Inheritance. Petrarch costinued his atudy of classical 11terature. It was the contrast between the glories of Rome and the contemporary stuation which Inspired Petrarch to begin a major work on the miserable condicions rife in Avignon. 27 Fetrarch's lack of interest In the political problems of the papacy is revealed in this unfinished treatise. So write a "tragedy" on the aubject of the "Babylonian Captivity" shows that Petracch was obsessed with what had been Irrevocably lost rather than with what the past could offer the present.

In 1330 Petrarch became reacqualnted with Giacono Colonna, earlier hls fellow student at Bologna. It was through Colonna's personal recomendation that Petrazch came into the service of his first patron, Cardinal Glovanni Colonna. Offlclally Petrarch was called "capellanus continuus comensalis" but his ecclesiestical dutles were only honorary. Petrarch functioned primarily as a table companion and resident scholar in the cardinal's entourage. 28

The patronsge of the Colonna family also gained Petrarch aduittance to the growing library of Pope John XXII. Besides the

27Emest Hatch W11k1ns, "Works that Petrarch Thought of Writing," Speculum, XXXV (October, 1960), p. 367.

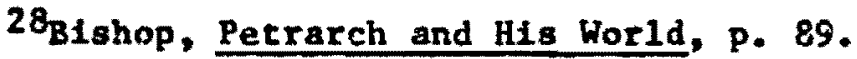


atudy of cannon law, John ordered coples, bade at his own expense, of classical authors. The firat extant catalogue of the papal library, made in 1339, 11sts two thousand volumes of ancient philosophy, science, and history alone. 29

The Colonna fanily also had a private library, augmented during the cardinal' frequent travels in France and Italy. Landolfo Colonna, the uncle of Giovanni, noved from Chartres to Avignon in 1328, bringing with his a fine copy of Livy's History [of Rome] from the Founding of the Clty. Petrarch compared this copy to an earlier edition of Livy which he had been editing. It was in the first and Third Decades that Petrarch found the history of Rone's expansion and her fight to the death with Carthage. He would embellish this account In Africa and The Lives of Illustrious Men. 30

The substance of Petrarch's early reading on Rone is Important In establishing the sources of his historical imagination. The religious significance of The Secret is also set off by determining the extent of Petrarch's knowledge of the Christian Fathers before 1341-42. In an effort to untangle the mystery, Plerre de Nolhac, Berthold U1lman, and Gulseppe Billanovich have stukied a marginal notation concerning Petrarch'g earliest collection of books. A list of his "specially prized booke," dacing from 1333, reveals a

${ }^{29}$ s. Harrison Thomson, Europe in Renaissance and Reformacton (Naw York: Harcourt, Brace, and World, Inc., 1963), p. 2.

${ }^{30}$ Gulseppe B11lanovlch, "Petrarch and the Textual Tradition of Lvy," Journal of the Warburg and Courtauld Institute, XIV (1951), p. 172. 
predominance of classical over Christian authors. 31 cicero, Seneca, Aristotle, Suetonius, Sallust, Livy, and Virgil take precedence over Augustine and other Church Fathers. This list has been used by varloes scholars to "prove" that Petrarch's early readings were blased toward the pagans and that he turned later to Christian scholars. Billanovich has discovered that Petrarch bought a copy of the City of God in 1325 and received Augustine's Confessions as a gift in 1333. 32 Mere ownership does not prove that these books were more important to Petrarch than the poetxy and history of ancient Rome. However, Africa and The Lives of Illustrious Men, the major works of these years, both celebrate the virtues of republican, pre-Christian Rowe. It is st111 Impossible to assert that Petrarch practiced any lasting discrimination against the Christian Fathers. More reveallag than ownership of certain types of books 18 Petrarch's shift from 1yric Italian poetry to the epic Latin atyle of Africa. Petrarch's nearly exclusive concern with classical antiquity is show by his growing interent in the Latin language. By exerting himself on the reconstruction of great classical works Petracch developed a rigorous phtlologiteal and rhetorlcal instinct for words and phrases of the ancients. Petrarch felt it necessary to write in I.atia because the language reflected not only a style of ilterature but the concrete reallty of the Roman culture. An intimate knowledge of VIrg11, LIvy, and Cicero Iuplanted

31 Berthold L. V1lman, "Petrarch's Pavorite Books," In Studies In the Itallan Reralssance (Rome: Edizionl di Storla e Letteratura, 1955). p. 118. P. 293.

32B1llanovich, "Petrarch and the Textual Tradition of Livy," 
a pleture of Rome in Petrarch's mind. Especially in his early years, Petrarch's vision of Rome vas more important to his historical imaginat1on than knowledge of the Christian Fathers or Trecento culture.

Petrarch vigited Rom for the f1rst time in 1337. Cardinal

Colonna responded to Petrarch's Interest In Roman culcure by granting hin leave to explore the "Queen of Cities." The rulns provided Petrarch with visual evidence of the truth of the anclent's words. Using a twelfth century guidebook of the historico-legendary topogrephy of Rome, the Wonders of the CIty of Rewe, Petrarch walked the city and wrote to Colonna.

Sitting at the Bath of Diocletian, as when we had clambered on the valls of the crumbly clty, we had the broken ruins under our eyes. We talked long of the city's history. We seemed to be divided; you seemed better informed in modern. I in ancient hiatcry. (Let us call anclent whatever preceded the celebration and veneration of Christ's name in Rome, modem everything from then to our own time.) 33

This letter vas the Inspiration for Theodore Mommen's classis study "Petrarch's Conception of the Dark Ages." Momsen percelves a net "humanist" periodization of history. He gives Petrarch credit for destroying the medieval 1dea of the continutity of Rone, from pagan througi thirteen Christian centuries. "Antiquity, so 1008 consldered as the 'Dark Age' now became the tiwe of '11ght' which had to be rescored. The era following antiguity or the other hand,

33Francesco Petrarch, Letters from Petrarch. selected and trans. by Morris Blohop (Bloouington: Indiana University Press, 1966), p. 66. Familiares VE, 2 (1338). 
was subwerged Ir obscurttg."34 Momen denles that Petrarch's sategorles wight be only a convenient latel. He assert that Petrarch IIntted ancleat history to pagan Rone on princtple, the obvious value Judgrent being a condernation tf the nediloval, Cariatian eza.

Petrarch's VLsion of Rcae 18 chronologically Inconsistent. We cannot accept Howsen's ldea of a new "tumanist" perlodization of history because Fetrarch did not set up an absolute standard. He endorsed the 1dea of continulty in condeming the Avignon Popes for breaking with nedieval spiritusl tradition, ie aiso criticized Charles IV for refusing the responsibilities innerent in the Caesarean Inperiua. On the other haad, Africa, The IIves of Illugtrlous Men, and Coronation Oration show Petrarch's strong sense of discontinulity between the past and the present. The periodization of history depended on Petrarch's Imediate enotional and rhetorteal needs. His realism in historical wethod and detafl was always conbined with an over-riding romantic ideal.

On returaing to Avigaon Petrarch escaped the hateful city and wth Colonna funds established hisself on a small farm at nearby Vaucluse. In this rural hideaway Petrarch worked on his first collection of noems and spent leleurely hours "vistting" with friends both allye and dead. In a letter to Glaccio Colonna in 1338 he explained the joys of Vaucluse with the company of his "secret friends."

34Theodore E. Momsen, "Petrarch's Conception of the Dark Ages," In Medieval and Renaissance Studies, ed. by Eugene F. Rice (Ithica: Cornell Univeraiky Press, 1959), P. 118. 
They come to me frow every century and every land, 111ustrious In speech, in wind, and in the arts of war and peace. Only a corner of my house they ask. They heed ny every sumona: at my call they are with me, ever welcome while they stay, ready to go, if I wish, and to return. . When I an bowed with sorrow they restore me; when I meet with Forture's favor, they restrain wy pride, reminding we that the days of itfe are fleeting. The humbleat shelter is to thes a mansion where, trembling they may 1Inger, t1l the clouds are gone, and til the Muses rule egain. 35

It 18 obvious that Petrarch does not fit into the Chrigetan ascetic tradition of the religlous contemplative. Dedication co literary rather than spirieual scholarship creates Petrarch's need for solicude. Petrarch seems to be aware of no conflict between sacular learaing and solitude: retirewent reans only detachment from hmantey, the uncultured mob, and not fron books. He admits that "180lation without literature is exile, prison, and torture; supply 11terature and it becomes your country, treedom, and del1ght." 36 In starik contrast to the clvic humanism of the Quaterocento. Petrarch did not deflne freedom and liberty in politfcal terms. In escaping from the political and social realleles of the Itallan city-states Petrarch galned a secure lelsure. He also rewoved himself from any possible understanding of current politics. The effects of this Inolation of Petrarch's historical imagination will be shown later.

It must also be remembered that Petrarch's unearned ecclesiastical Incowe allowed him to celebrate the virtues of rural living without

35 Francesco Petrarch, Petrarch at Vaucluse: Letters in Verse and Prose, selected and trans, by Ernest Hatch Wilkins (Chicago: University of Chicago Press, 1958). p. 9. Eplstolae Metricae.I, 6.

${ }^{36}$ Francesco Petrarch, The Life of Solitude, trans.by Jacob Zeftlin (Urbana: University of IIlinois Press, 1924), p. 131. 
belng a farmer. Petrarch's ecclestastical appolntwents consefeuted the main source of his livelthood. Ernexc Hatch Hilkins speculates that Petrarch did not take even the minor ozders. He was able to hold benefices only beeause the theoretical gequirements were rarely enforced. 37 petrarch never accepted any duties which would have interfered wich hs literary pursults, but he valued the lincore as a means of atcalning freedow to work. At varlous times in his life Petrarch held beneflces in Lomber, P1sa, Parma, and Padua.

In 1338 Petrarch conceived the idea of the fifica, his first major work dealing exclusively with Roman history. Africa is a poetic Incerpretation of Scipio's conquest of Carthage in 202 B.C. Petrarch developed the theme of an eplc struggle of two civilizations for control of the world, exphasizing the place of Scipio as the Rowan man of action and illtary hero.

Africa yas structured as an epic neant to reveal the birth, death, and resurrection of Rome. It was, however, also a flctional biography siace the role scipto plays carries hin through all eras of pagan, Christian, and modern rime". Petrarch wrote Africa as a glerification of Roen hiatery in order to wake up the unorthy and un-Rosan wea of his time. To give his consemperartes a sense of what had been $108 t$ asd what must be rebuilt, Petrarch distorted the conventional bouncarles of historg to suit his purpose.

37 Ernest Hatch Wilkins, Studies in the life and Work of Petrareh. (Cambridge, Mass.: The Medieval Acadexy of Anerica, 1955), P. 3. 
Petrarch's hiscorical sources were Cicero's Dream of Sciplo, Macrobius' Commentary on the Dream of Sc1pio, and Livy's H1story of the Punlc Wars. 38 Petrarch granted Sc1p1o a far more critical role In the drama than hivg. To give the everts epic proportions it was necessary to embellish the hero's personality with mythical qualities.

Publius Cornelius Scipto Africanus the Elder exemplified the pagan and military virtues of the Roman Republic. Petrarch, however, eredited his with both the 1mediate salvation of the state and with prophesying the satablishwent of Rowe as the capital city of Christianity. Selpio is to Petrarch both an historic and poetic figure. H1s persoaality as developed by Petrarch symbolizes the moral state of Rome as vell as a unique historical personality of the Republican era. Inasmuch as the intent of Africs is to inspire heroic action in present-day Italy, Petrarch allows Sc1pio to coment on Roman istory through the centuries. H1s words break down the pagan-Christian historical distinction and cause Petrarch to say, "Oh, remarkable worda worthy not so much of a young milltary leader, as of an elder or a lofty poet, or a distinguished philosopher, or even an apostle."39 It 1s the duty of an historian to transform wen by means of the "burnIng" power of words. Sc1p1o's eloquence 18 one of Petrarch's methods to make the now absent Rosan beritage come allve in the present. While Scipio is the hero of Afica, it is important to note any reference Petrarch makes to Caesar so that a comparison can be drawa

$$
\begin{aligned}
& 38_{\text {Beraardo, Petrarch, Sc1p1o, and the Africa, p. } 163 .} \text {, } 39_{\text {Ibid., p. } 61 .}
\end{aligned}
$$


betweed his pouthful and mature ilstorical outlook. The subject of Africa la Republican Rome and its struggle with Carthage. This is a change fros the dedieval conception of the Romal Eapire as the "Mnaaschy egtablished under Caesar, extended under Augustus, restored under Trajan, fustified usder Constantine, set in order by Jusrinian, consolidated under Theodosius ad strengthened anew inder Charleragne:40 However, the dividing IIne between the political ingtitutions of Bepublican and Imperial Kom is not so clear in Petrarch's wind. Hans Baron polnts out that Caesar is bitterly censured in Africa for "turning his ever victorious hands against the flesh and blood of his own comonwealth." 41 Yet Petrarch condewn that very comonwealth for not allowing Sclpio independent and unlimited leaderahip, forcing his to share his power with other cltizens.

It would be most falr to say that at this early date there was no contest between Sclpio and Caesar's political methods. Scipio was the Roman heto because Petrarch as yet knew litcle of Caesar's personalfty and the figure of Sclplo offered him greater poetic and moral possibilities. The discovery of the historfcal Caesar through the personal reminisences of Clcero would take place only after Petrarch recovered the Letters to Atticus in 1345.

Petrareb's conviction that Italy enjoyed the apecial favor of God led to his destruction of the boundartes of listory in ozder to dewonstrate the continutity of Rone's divineiy ordained rule. The

40Hans Baren. The Crisis of the Early Itallan Renalssance (Princeton, H.J.: Princeton University Press, 1966), p. 154.

41Baron, "The Evolution of Petrarch's Thought," p. 34. 
precepts and personages of the pagan exa fuse wth those of the

Christian in an incongruous fashion.

When David was born Rone was born; then 1 t was that Aeneas coe from Troy to Italy, which vas the origln of the most noble Ronan cfty eyen as the written word bears witness. Evident enough therefore is the divine election of the Roman Empire by the birth of the holy clty, which was contemporaneous with the root of the race fron which hary eprings. 42

A scene in Heaven before the throne of Jove-Jehovah relterater this thewe.

I w111 put on flesh, descend to earth, accept the burdens of humanity, and suffer a shaweful death. Rowe w111 be my Holy City and I shall cowe soon so captured I by a plactd Virgin, 80 allured by her breasta filled with sacred wilk. 43

By adding fecets of Jove's personallty to the Cnristian God, Petrarch creates a sease of continuty of rellgious sradicton while still allowing the pagans to be non-Christian in chronological time. In Petrarch's wind, it is only the gap in historical tiwe which separates bie frow the anclents. Mere difference in reilglous rituals was no obstacle to men who shared the common wisdom of the ages.

To prove the divine ordination of the Rowan Eupire Petrarch uses the concept of continutty in an unmedleval way. The re medleval Chrlastans comected thewselves with Rowe through a politicomrellgious cont1aum, Petrarch stressed the spiritual proximity of pagans and early Chrtatiana.

${ }^{42}$ Quoted by James Haxvey Robins on in Retrarch: The Flrst Modarn Scholar and Man of Lettera (New York: G. P. Putnan's Sons, 1914), p. 98 .

43uoted by Bishop in Perrareh and His World, p. 178. 
Petrarch ahifts ground agein in his discussion of the lack of political continuty between ancient and modern Rome. In order to slight his un-Rowan age Petrarch now separates Roman virtus from the succeeding period of forelgn barbarism.

The scepter and the dignity of the Explre, won by us with so much sweat--forelgners will steal it, men of Spanish or African origin. Who can bear this rise of the scuin of the earth to this bighest dignity-of people who were spared by the sword for Ignominious survival? . . The Empire will always be called Rowantu Imperium; but the Roman will not always hold the reins... In the end, the power will fall to the North. 44

It is clear that Petrarch draws no constant line between the ancient and modern perlods. Even Roman history is distorted to suit Petrarch's needs. The Roman Republic and Rcman Empire are used Interchangably because they both embody partial Ideals of Petraxch's vision.

The tranaformative power of poetry lies in its ability to create truth through illusion. Petrarch used the diatortive power of poetic symbols to inspire ethical action in bistory. In the introduction to Africa Petrarch admits "the role of true poetry is to take the very stuff of history and philosophy and recast it within a delightful and colorful cloud and thereby transform it into a goad to virtue. $" 45$

In his first Eclogue Petrarch distinguishes between the poetry of Africa and religious poetry by opposing the epics of Homer and Virg11 to the rhywes of David. David "wakes frequent references to ${ }_{44}$ Quoted by Momisen in "Petrarch's Conception of the Dark Ages," p. 118. p. 7.

45Quoted by Bernardo in Petrarch, Scipio, and the Africa. 
the cltizens and waile of the little Jeruaglas and never wanders from there and is always ready with tears and brtathes too hoarsely in his breast." 46 Homer and V1rg11, on the other hand, "ging of Rome, Troy, the battles of kings; the power of grlef and love and wrath, the spirit that rules the waves and the winds and the stars." 47 Religious poetry in general was limited by tzs ocher-worldiy concerns. Thus to Petrarch's wind the werging of pagan and Christian truth in the manner of Afrtca was the stuff of great poetry.

The dedication of Africa to Posterity revesls better than any other early document the psychological atate of the youthful Petrarch. Scipio's coapanion, the poet Enntus, foretells the future role of Petraxch In upholding the Roman heritage during thetr double "coronation" on the Capitoline.

I seem to see a young man born in the land of the Etruscans who w111 retell your explotes like a second Enntus... He will stay the fleetng Muses yith his songs; he will prolong our IIfe on earth. I love him for his services to us. He will be Insplred not by force, mcney, fear, hate, ambition but only by admiration for our great deeds, by love of truth. 48

The Idea that artists, th1nkers, and writere could stand together wth nen of action in Heaven is reflected in the end of Africa. The double corouation of Sciplo and Ennise shos the equal 1aportance of the poet to posterity as the mediun through which the actions of

46 Aido S. Beraardo, "Petrarch's Attitude Toward Dance," Publications of the Modern Language Assoclatior, LXX (June, 1955), p. 202. p. 202.

47Quoted by Bernardo in "Petrarch's Attitude Toward Dante,"

48 Quoted by Blehop in Petrarch and His Wor1d, p. 178. 
Individuals enter the hlstoricel tradition, Petrarch did not merely allow the prediction of Enaiue to stand but barges back through time to anmounce:

Ennius stood at Sclpio's rlght, also crowned with the laurel, and as cultivator of studies and of divine poetry enjoyed a gimilar tricuph as his great patzon. After these, many others followed In eager striving. I myself after fifteen hundred years, have attempted to cilab the thorny path and to follow the rare footsteps of thy predecessors but wh infericr power. Inttating the great triumpis of ancient heroes, lest the
predictions of the Greek bard should have been in vain.

Petrarch had done his duty by writing Africa. However, he was hesitant to release his book to scholarly friegds, much less the general public. Petrarch feared it would have no effect on his dark and barren times. "My fate is to live anid varied and confusing storas. But for you, perhaps, if as I hope and wise, you [Africa] will I1ve long after ne, there 111 be a better ege. This sleep of forgetfulness vill not last forever."50 Petrarch hated the "barbarians" control of current Roman polleles less than thelr disregard for poets and aen of letters. Africa would not be revered in the unscholarly present. It would be the future age which would judge the merit of his work. The dedlcation to Posterlty reads,

Do thou, my Afrtca, remenber to keep my name fresh. Thanks to thee way fame visit my tomb and honor atcend my ashes. Life will be sweeter to me among such a people, wy glory 111 defy the grave. Traverse, unknown, the stccession of heedless generations, lodging only with som rare, humble friend until the new age shall cone. Then saswe a nes youth when the light

\footnotetext{
p. 43.

${ }^{49}$ Quoted by Bernardo in Petrarch, Scipio, and the Africa,

50 Quoted by Mowasen In "Petrarch's Conception of the Dark Ages," p. 127.
} 
kind to poets shall ghine and an age shall dawn to bless and favor all good men. 51

The Lives of Illustrioug Mer, begun in 1338 and greatly modified between 1351 and 1353, Is Petrarch's atcempt at blograpty as history. In the preface Petrarch gives a succinct definition of the task of an historian. "Indeed if $I$ an not aistaken it 18 the frultful task of the historian to make known that which the reader should inteate and which he should avoid so that of these two a number of 1llustrious examples are available. "52

Here is in the Africa, Petrarch assues that the persuasive power of the historian cones from the eloquence of his speech and the cholce of his models. Petrarch remarks in Famillar Letters I, 9

How much eloquence can accomplish in the shaping of human iffe 1a known both from reading in wany authors and from the experience of everyday life. How great is the number of those we recognize in our own day to whow even examples of vircue were of no help, who have been aroused and turned suddenly from a wost wicked maner of 11 fe to a ferfectly ordered one imply by the sound of others' volcee. 53

The purpose of The Lives was to show, by extolling virtue and glory, that the undisputed greatness of Rome rested basically on the actions of 1ts great men. Petrarch was specifically concerned with the actions of "11lustrious" wen rather than accidents of fortune. He condens

5IQuoted by BIshop in Petrarch and His Vorld, p. 179.

52 Quoted by Theodore E. Mommeen in "The Sala Virorun Illestrium," in Medieval and Renatssance Studieg, ed. by Eugene F. Rice (Ithica: Cornell Uaiversity Press, 1959), P. 174.

53 Quoted by Jerrold E. Slegel in Rhetoric and Philosophy in Renatasance Himanism (Princeton, N. J.: Princeton University Press, 1968). P. 34 . 
his ow age for an strophy of w11, the results of which are evident Is the current poitical steunctori.

I thank our princes who save we-feeble and desirous of quietfrow such effort, for they fumish aterlal not for history but for satire. And if I know some tho of late have been remarkably ouccessful, all their victortes were gained elther throwgh good luck or the tnert1a of their enewies, and chere was no glory or virtue involved at al1, 54

Petrarch sees human indtlated action as the driving force of history. The Idea that "11lustrious men" could aske history was highly secular. Petrarch breaks with nedleval tradition accoxding to which all history 1s ruled over by God. 55 The Lives of Xllustrious Men was Petrarch's flrst celebration of Individual personality. The Deeds of Caear (De Gestle Caesarifs) written in Petrarch's old age, would be his supreme example of this genre.

The importance of The Lives to Petrarch scholarship centers on the chronology and persons of the 1338 as compared to the later plan. Through a false reading of Plerre de Nolhac. Theodore Momsen assumed that what was orlginally concelved as a blography of "all the 111 ustrious men of all countries end ages" became in time condensed to a consideration of Boman heroes alone. 56 Nolhac thought The Lives celebrated the lives of Rosan heroes from King Lomulus to Enperor Iltus in the final version. However, the work of Carlo Calcaterra 54 Quoted by Mommen in "The Sala Virorum Iliuserium." p. 136.

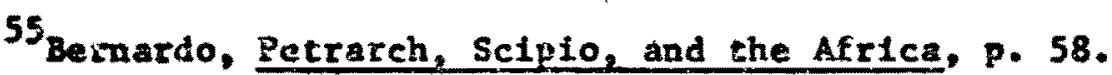

56 quoted by Mormsen in "The Sala Virorum I1luserius," F. 172. 
and Guido Martellott on the 3351-53 reviston shows that the biofraphies of Adan, Woah, N1mrod, Ninus, Semiramis, Abrahsm, Issac, Jacob, Joseph, and Moses were added later to those of the Romans. 57 It is therefore through or in response to the religlous introspection of the Secretum period that the Biblical heroes came into thetr own. This discovery of the revision of The Lives of Illustrious Men to Include religlous figures ohows a broadening of Perrarch's historical Iragination. The addition of Biblical heroes to $\mathrm{a}$ formerly Roman scenario reveals Petrarch's wilingmess to shift the boundartes of hiatorlcal time. Mommen's concept of ages of darkness and 11 ght did not exist absolutely in Petrarch's mind.

In his early gears Petrarch's reputation depended prisarily on his Italian love poews. The author wished instead to win glory through his Latin works, Africa and The Lives. His reading of the ancients acqualnted Petrarch with the long-lost tradition of the laurel crows, a custon of honoring poets which had been discontinued for twelve hundred years. In the days of Imperial Rome there had been held on the Capltoline, once every five years, a multiple contest that included a prize for poetry. 58 The Itallan poet Mussato had been crowned wth the laurel in Padua in the early fourteenth century, but Petrarch, In line with his poetic and historical sensibility, believed Rowe alone could crown a worthy poet. In not too subtle letters to King Robert of Naples and the Colonna famlly, Petrarch hinted that

\footnotetext{
57 Referzed to in Bacon's "The Evolution of Petrarch's Thought," p. 25 .

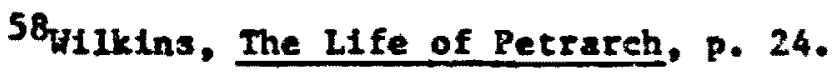


the revival of this custon would help bring back the glories of old Rowe by Inspiring eplc potry, his Africa being a prime exaple. Wuch to his surprise Petrarch recelved stmultaneous invitations for a coronation from both Paris and Rome cn September 1, 1340. Writlas to Cardizal Colcane Perrarch justifles his cholce of Rore.

The charm of novelty urges me toward Paria and reverence for antiquity toward Rome, on the one hand my fitend, on the other n fatherland. One tligg that wefghs with we is that the King of Maples, who is in Italy, is the one man whose judgaent as to wortiness I should be content to accept. 59

Petrarch always enfoyed the pralse lavished on hin by Robert the Wre of Naples, chtef of the Guelphs and the Papacy's main ally In Italy. At one time he even considered writing a treatise devoted to Robert's resurrection of the classfcal cradition in the court of Naples. 60 Robert did, in fact, cultivate a scholarly revival by supporting the Ualversity of Naples. Alded by Arab and Greek translators, Robert collected a private librery and wrote a treatise advocating evangelical poverty. 61 Robert, however, hardly deserved Petrarch'a epltaph of a "secosd Plato of the intellect."62 As a patron of the arts, Robert boped his sponsorship of Petrarch would drav the poet to a permanent residence at his court.

Before visiting Rone in Apr11 of 1341. Petrarch traveled to Maples to recelve a three day "oral examination" from the klng, who

${ }^{59}$ Petrarch, Petrarch at Vaucluse, p. 26, Fantl1ares IV, 4. 60 W11kins, "Works that Petrarch Thought of Hriting," P. 564. 61 Tatan, Fracesco Petrarca, p. 106.

${ }^{62}$ Quosed by Tatan In Francesco Petrarca. P. 104, Fandliares V, 1 (1343). 
pronounced hin fit to wear the crown. In a letter to Robert Petrarch acknowledges the historical 1mportance of the revival of the crowning of poets.

In this zestoration of the custon of the laurs1-not werely Intermitted for many ages, but altogether forgotten while very different cares and studier prevalled in the Republic--you have been the general, and I the corron soldier. I know men of the highest gifts, both in Italg and abroad, who have only been deteried from the attempt by its long disuse and by the suspicion attaching to novelty; and I trust-now theg have ladd the peril on wy shoulders--that they will shortis follow in my wake and pluck the Roman laurel by rivalry in study. Who can deny, or fear to comence the march under the auspices of Robert? It is a delight to be the first in such an arny, of whIch I should think it not inglorious to be the 1ast. I confess that I should have been unequal to the burden, had nor jour favor given we strength and courage. 63

It had been a dry age for scholars in general and poets in particular

The Africa was written with youthful enthusiasm and arrogance. In the same positive spirit Petrarch defended poetry in his Epistolae

Metricae II, 2.

You call us mad? Well our madness is divine. Dreamiag is the singers right. Only when $1 t$ soars can the soul, escaping mortallty, sing of exalted things, leaving the vulgar mob far below its feet. You would drive us from your eities; but we love the woodland solitude! Who will remain to teach you the 1deals of the past, valid for the future? If poets were aute, man would be mute also, and virtive would hide unknown, lovely only to itself, and all the great past would vanish, and even the fundarentals of our languagel True, Aquinas warns that praise of poets will bring worthless ones to the fore. But that 18 the common case; it is no argument againgt the sublimity of the great, such es Vergi1, who hide sublime trisths under a deceptive clariey. 64

63 Ibld., P. 154, Faniliares IV, 7 (1341).

${ }^{64}$ Quoted by B1shop In Petrarch and His Wor1d, p. 260, (1345). 
Hete is Petrarch's strongest statevent ou the power of the poetic word. In asserting the alo of poetry as teaching and persuading, Petrarch denled the wedieval defiuttion of poetry ss mere decoratior. The triump of virtue could becouse a reailty because poets were able to reveal truth in a pleasing and iaspiring wanner.

Petrarch was crowned on the Captcoline on Apri1 B, 1341 and h13 Coronarton Oration is an unrevised statewent of the poetic theory and patriotian of his early years. He admits to the crowd

As we all read and know, there was on age that was happler for poets, an age when they were held in the highest honor, first In Greece and then in Italy, especialiy when Caesar Augustus held imperial sway, under whom there Hlourlshed excellent poets, Virgil, Varius, Ovid, Horace, and many others. 65

Petrarch uses the fact of she twelve-hundred-year break between the last and his present coronation to 1 aply that there were no medteval poets of sufficient valor and style to win the crown. He thus sees himself as the logical-chronolcgical successor to Homer and Virgil.

I finally decided to come to Rome-why I ask you if not for the very reason that Virsil says 'Vlcit Amor Patriae.' I was much moved to this decision by a certain affection and zeverence of those arcient poets who flourished in this very city, who lived here. who are burled here. 56

Ignoring the fact that Rowe the fourteenth-century city could not posaibly be compared to Rome or the Empire of antiquity. Petrarch views the revival of this custom as a logical recogation of Rome's continuing greatness. "I an moved also by the bope that, if God w11s,

65 Francesco Petrarch, The Coronation Oration, trans, by Erneet Hatch Wilkins in studies in the LIfe and Work of Petrarch (Cambridge, Masa.: The Kedieval Acsdemy of America, 1955), p. 305.

66 Ibid. . p. 305. 
I may renew in the now aged Bepublic, a beauteous custon of itg flourishing youch." 67 . In asking himself a thetorical question, Petrarch gives an indication why chis evart la so laportant to hise "Do you not see what a task you have undertakea in arteupting to attala the lonely steeps of Parnassus and the inaccessible grove of the Muses?" 68 Yes, he does sae, tut a "sweet longing urgea we upwards over the lonely slopes of Parnassus" where hopefuily he way come to rese with the great clasalcal poets. 69

To reach the level of the poets of antiquity Perrarch inicated them as closely as his iagination allowed. The structure and style of Africa was so "eple" that contemoraries considered it a cultural "artifact" before it was even fintshed. The Scipio that Fetrarch carefully developed was atill only a poet's hero. The popular culture had no knotledge or interest in such a bythlcal personality. It Is doubeful that wany people took notice of Petrarch's coronation. The ceremony that was to symbolize the dawn of a new 1tterary age did, however, have a powerful effect on Cola di Renzo, a man whose polizical romanticism tied hia closely to Petrarch. The style, and emotion of the Coronation Oration allenates it frow fourteenth century culture. Petrarch in fact directed it at his apiritual cowrades Cicero, Virgil, and Homer. The workings of Petrarch's historlcal insglaation had again bridged the gsp between the real and the Ideal.

$$
\begin{aligned}
& 67_{\text {Ibid., p. } 305 .} \\
& 68_{\text {Ib1d., p. } 304 .} \\
& 69 \text { Ib1d., p. } 304 .
\end{aligned}
$$


Petrarch began work on the Secret (Secretua) in October of 1342 and ccapleted it by March of 1343. It was his E1ret major work af ter the Coronation Oration and stando in marked contrast to all his earller york. Petrarch's bold optimisn and imagtnative Identification vith antiquity are negated. Here for the first time we see Petrarch's Insecurtity expressed In a religious context. Juxtaposed to Africa, The Liyes, and the Coronation Oration the "Secretum crials" reveals Petrarch's spiritusl Intrcapectioa. It is an Imortant paychological record preclsely because it followed period of Petrarch's greatest optialsm and creativity. We do not know, houever, the exact cause of his religlous intereat.

Petraxch wrote The Secret in the form of a dialogie between himself and Auguseine. Petrarch had acquired the Cicy of God and Confesglors in his youth. Augustine'g theology was not his anjor concern. Petrarch Instead emphathized with the "paradigmatic quality of the Salne's own expertence of wanderting ambivalence, prychic division, and ultiate resolution of his conflict."70 where classical authors Influenced Petrarch's historical outlock, the convereion of Augustine becave a codel for his splritual development. Petrarch states the Importance of the Confessions at a turning point in his 11 fe.

I vowld have you know that book was the reans of introducing ae to the whole of aacred literature, which In wy arrogant youth, wth a young wan's insolence-as I now see--at the suggestion of the devil, I had avolied as low and unequal to secular writingsm-

${ }^{70}$ Charles Irinkhaus, In Ous Image and Likeness: Humantey and Diviniey In Itallan Huranist Thoughe (London: Constable and Co.. 1970). I, 14 . 
so great was my lore of the latter and cunteupt of the former. and 80 false wy estimate of myself. That book so radically changed ae. I do not say that I abandoned my early vices but that henceforth I neither desploed nor hated sacred letters. Nay, their rude simplicicy soothed we and drew wy unilling eyes and ears towards them. In short I began to love and adnlre them and to draw fewer flowers, perhaps, but wore fruit from the than frow those I had formexly so loved. It would have been strange for a Christian to have been in no wize changed by the eloquence of Augustine when, as he records, the 'Hortensius' of Cicero had so changed him. 71

The main content of the crisis which took witten form in The Secret 18 Petrarch's dental of the value of classical studies. He shall see, however, that Petrarch adopts a Chrlatian cone only for a short ยIne.

The ceatral dialogue of The Secret concerse Augustine's attack and Petrarch's vehement defense of the two finest psasions of his nature, love and glory. A coademing Augustine sqates,

Not being contented with you duty of evary day you have let your thoughts run on ages of time and given yourself up to dreams of fame anny those who come after. And in pursuit of this end, putting your hand to greater tasks, you entered on writing a history from the tire of KIng Romulus to that of Emperor Titus, an enormous enterprise that would swallow up an imensity of time and labor. Then, without walting tll this was finlshed, goaded by the pricks of your ambition for glory, you salled of 1 in your poetical barque towards Africa. Throw to the winds those great loads of historles; the deeds of Romans have been celebrated quite enough by others and are known by their $9^{\text {wn }}$ fame. Get out of Africa and leave it to 1 ts possessors. 72

This critictsm atzikes the heart of Petrarch's personal beliefs. Angustine condems Fetrarch's interest in ancient bistory and I1terature. Horeover, Petrarch's spiritual conscience denies that poerry

71Quoted by Tatan 1a Francesco Petrarca, p. 236, Sen1les VIII, $6(1367)$.

72Prancesco Fetrarcin, Petrarch's Secret, trans. by Willian H. Draper (London: Chatro and Hindus, 1911), P. 169. 
can have any active meaning in human history.

Petrarch protests that Africa is his prize and clatm to etermal fanc. This gives Augustine an opening to reflect on the mortality of all human ereations.

First there 18 the death of those with whom one has passed one's life; and that forgetrulness which is the corsaon bane of old age: then there is the $t$ lsing fare, ever growing greater of new men; Think, too, how fickle is che judgzenc of the cultitude. In your own Africa you call this, elegantly enough, the second death. And then consider the perishing of books for even though that perishing way appear so much more delayed as books outlast monuments, nevertheless it is sooner or later inevitable. When your books perish you shall perish too; this is the third death to be endured. 73

These words constitute a devastating attack on Petrarch's professional goals. Bowever, he did not belleve his writings would not outlive hil. The "Secretum arisis" did not radically change Petrarch's life. He contiaued to use Christian models but did not give up his literary leisure for a conastic retirement. Aspiritual revaluation of Petrarch's priorities was a necessary response, modifyIng his youthful egoism.

Petrarch discovered a codex containing Cicero's Letters to Atticus, Brutus, and Quincus while visiting Verona in 1345 . The recovery of this 1ong-lost source challenged Yetrarch's opinion of cicero and inspired the collection of his own letters. Petrarch learned of the private 1 ives of ancieat Romans in shese letters which "threw a flood of light on the struggle between Caesar and Ponpey and upon the personal character of cicero biaself." 74

$$
\begin{aligned}
& 73_{\text {Ibid. , P. } 180 .} \\
& 74_{\text {Tatam, Fraucesco Petrarca, P. } 350 .}
\end{aligned}
$$


Sometiwe betwcen 1345 and 1350 Petrarch began collecting and editing his private lettera. Cicero and Sencea were the models by which Petrarch charted his ow development. Petrarch was intent on presenting himself in frogress toward vircuous goal. Constant revision of the letters ellminated any matters which could damge Petrarch's reputation. He suggests,

In the ordering of these letters I rook accoint not of the subjects but of the time of writing. Except for the last few, written to 111 ustrious men of old, which I brought together in one place because of their unity of character, almost all the letters appear in the order in which they were writcen. Thus the reader, if he is at all curious about it, may follow my own progress and understand the course of 1 ife. . . Now to thee, worthy reader, whoever thou art, I beg and pray, by our comon zeal for learning, by thy care for thine own fame, be not affilicted by the variety of my subjects or ny huble etyle. 75

Petrarch goes beyond mere explanation in addressing an assumed

future reader. He sought notice only of the progress in his 11 fe.

Letters reflecting lmature viewe were changed to match his later

experience. Exposure to the personal character of cicero in the

Letters to Attlcus made Petrarch very conscious of the damage done

by the written word.

Petrarch responded to the Letters to Atticus by sending two lezters to "Cicero in Hades." For the first time Petrarch recognized the diffezence between Cicero the Otator and Cicero the political chmeleon and civic philosopher. Petrarch was horrified with the new historical person he discovered. In anger and dismay Petrarch

\footnotetext{
75Petrarch, Letters From Petrarch, p. 212, Faml1ares XXIV, 13 (1361).
} 
refused to accept cicero's words. Oaly by reading between the lines and attributing hidden meaning to sinple statements did Petraxch malntain his bias.

In the Midle Ages tho moral philosophy and the platonic overlag of Macroblus in his Comentary on Scipio's Dream turned Cicero Into a contemplative philosopher. As Hans Baron points out, Macrobius' ain was "To Frove that CIcero, in splte of his championship of active political life, had already known chat religlous contemplation was on a higher piane." 76 Another sedieval source was the adaptetion of On Public office as a guide for the use of clerics and laymar by Saint Ambrose. 77

However much Petrarch vas aved by Cicero' golden eloquence, comon sense, and noral wisdom, Cicero's civic spirit was incomprehensible to him. The cultured man of letters had been pulled into the fires of the Civil Wars by what Petrarch considered skewed priorities. He asks

Why did you choose to Involve yourself in so many vain contentions and unprofitable quarrels? Why did you abandos the retirement proper to your age, profession; and fortune? What falbe dazzle of glory led you, an old man, to Implicate yourself In the rars of the yourg? What tempted you to dealings that brought you to a deach unworthy of a philosopher? How nuch better it would have been for you, the phllosopher, to have grom old in country peace, weditating on the eternal life, not on this transt tory existence. How wuch better if you had nuver held the fasces of power, never longed for triumps, never corrupted your spirit with any Catalines. 18

76Hans Buron, "Cicero and the Civic Spiriz In the Middle Ages and Early Renalssance," Bulletin of the John Rylands Library, XXII (1938). p. 77.

$77_{\text {Ib1d. }}$. p. 79.

78parrarch, Lecters from Petrarch, p. 207, Paililarea XXIV, 3 (1345). 
The great histortcal integest of Petrarch's relation to Cicero In Baron's words, "11es in the fact that $1 t$ allowa to to see so clearly the unconscious connection between the way of ilfe of the himanist 11terati and the wonarchical interpretation of Rowan history."79 The "Letter to Clcero in Hades" shows Petrarch to be a partisan of Caesar. He does not aduit any glory in civic service, eaphasizing Instead the trials and danger. Petrarch sought freedom frov the anxteties of the republican forum and therafore advocated quet retreat from public involvement. Petrarch knes cicero only as a philosopher and $h 1 s$ exemplar. CLcero's herole response to the Cataline Conepiracy was, to Petrarch, a corruption of the phllosophtc spirit. It is Clcero's mixing of literary and political culture that irks Petrarch. It was an old Clcero who entered Republican office, glving up his scholarly solitude when he should have knom better. Cicero's Letters to Atticus revealed a petty bitterness and a vast alount of mumdare conserus in his iffe. Petrarch had not seen these things in the brilliant publlc orations of clcero. These letters brought into clear focus the personalities, Including strengths and reaknesses, of Cicero and Cassar. Petrarch, therefore, Ifke Clcero, fluctuated between love of Caesar's power and person and hatred of hia tyranay. The ythical name of Caesar was already well established in the Midile Ages. Petrarch vas unable to percelve Caesar werely as an often viclous pollzical animal, the wan Cicero

79 Baron, The Crials of the Early Itallan Renatsance. p. 122. 
responded to. Friedrieh Gundelf adnits,

No docbt Petrarch, too, Intoxteated hirself with the past glory of the old republic and wept with Cicsrontun eyes over its fall: but these were not political tears for the downfall of an ideal but an eesthetic melancholy among ruinsm-not an expression of his bitter grief over an tmpotent deed, but rather his almost voluptuous sense of distance and transclence. 30

The coatrast is great between the historleal Republican and Imperial Rome, the Rome of Scipto and Cresar in Petrarch's terms. Yet Petrarch's pralse of both eras is not inconsistent. The polftical Institutions of a republic and an empire differed far wore than the apirit of the great wed who directed them. Clcero wasted his ilfe In trying to save the already dying state. This is why Petrarch dondems him for attempting to salvage Scip1o's republic.

I owit your treatment of Julius Caesaz, whose well-sested clemency set free even those who assalled him. I say nothing of Pompey the Great, with whom, it seewed you were on such a friendly footing. But what frenzy provoked you agalnst Mark Anthony? Love of the repubilc, I suppose you would say, but you aduit that the republic had already totally collapsed. And if fidelity to the state and love gf liberty lmpelled you, why were you 80 famillax with Augustus? 81

Many of these are the 8 ane questions Boccaccio and other Isalian

frlends would ask Petrarch after his move so Milan. It is natural

that he asked them of hls own exemplar.

Petrarch's second letter to Cicero takes a nore apologetic tone.

If you $\times 111$ permit my frankness, Cicero, you 11 ved as a man, you spoke as an orator, you wrote as a phtlosopherl It was your 11fe that I cenaured, not your aind, not your tongue. I admire your mind, I ex bewitched by your tongue. And in your life I

80 Frfedr1ch Gudolf, The lientle of Cresar (Hew York: Vanguard Pres8, 1928), P. 126.

81Petrarch, Letters from Petrarch, p. 207. 
ask ooly conatancy and that taete for quiat which is proper to the practlce of philotophy, and withdrawal frow civil strife, when only liberty was dead and buxled and the republic tearfully interred. 82

Petrarch's view of Clcero is completely rowantic. He had evidence of the historical reality of Cicero's life. Yet he still distinguishes between the positive contribution of Cicero's philosophy and his fatal political actions. Clcero's wozds beultched Petrarch. The golden speech of the orator was acceptable. However, Petrarch continued to censure Cicero's life by ignoring historlcal fact.

The discovery of the Letcers to Atticus was of great importance to the development of civic humanism. Petrarch's clcero was not... accepted in the fifteenth century but the same documents were used to celebrate Clcero's active 11fe. Petrarch underatood the disturbing evidence introduced in these letters and realized a debate would arise between supporters of the contemplative scholar and those of the active citizen. Petrarch in fact advises a "fanatic admirer" of Cicero to

remember that they are things conceming which no unblased judgment can be formed, by you or anyone else, without a careful reading of the entire correspondence of Cicero, which suggested this controversy. 83

Besldes Clcero, Petrarch irote to Seneca, Varro, Quint1llian, Livy, Horace, Virg 11 , and Homer. The Letters to the Ancients offers us unique pexception of the spiritual comuaion which tied Petrarch to the great men, now dead, of a great age, now gone. He says,

$$
\begin{aligned}
& \text { 82Ib1d. p. 210, Fan111ares XXIV, } 4 \text { (1345). } \\
& { }^{83} \text { Ib1d., p. 203, Faniliares XXIV, } 2 \text { (1352). }
\end{aligned}
$$


"Frlendohip binds to the nawes and ashes of the 11lustrious dead of every 8ge, no 1 ess effectively than $1 f$ the were al1ve. $\$ 84$

Petrarch was aware of the enf gmatc quality of his letters. The concluding entences often find hiv realizing they were not dellverable. Immediately the tone and tense switch from a comunication between contemporaries to a statesent of fact frow the "land of the 11ving." 85 Petrarch's Letters to the Anctents are atterpts to escape out of cultural barrenness Into a more comfortable and productive climate. In his "Letter to IIvy" Petrarch concludes, "For this especial reason I render thee thanks; that thou didst so frequently cause to forget the present evils and transfer me to happler tines." 86 Unfortuately, thls 111 usion can only last a short time and Petrarch sees that he 18 at111 trapped.

For a long time I have been talking to you just as if you vere present; but now the strong 111 usion fades away, and I reallze how far you are from ae. There comes over we fear that you w111 scarcely care, dowg in the shades, to reed the wany things I have written here. 8 ?

The Letters to the Anclents are a rhetorical Innovation In the history of l1terary style. To Petrarch they were also one way to overcone gapa In historical tiwe by flights of poetic Imagination.

84Prancesco Petrarch, Petrarch's Letter to Classical Authors, trans. by Marlo Eallio Cosenza (Chicago: Univeralty of Chieago Rress, 1910), p. 113.

85 Quoted by Peter Burke in The Renalssance Sense of the Past, p. 22. 86Petrarch, Petrarch's Letters to Classical Authors, p. 100. 87Ib1d., p. 156, "Letter to Homer." 
Ife in Avignon was intolerable to Petrarch during the time of Pope Clement VI. The buliding of a huge palace to house the pope, curla, and multitudes of relative was the surest lndication that the Holy See was not about to return to Rose. The situation in Italy worbened rapldiy just before mid-century. Bernabo Viscont1 at cerpted to carve out a sate in northern Italy alded by Pope Benedict's policy of appeasement. Clement VI resumed a warlike policy against the Visconti and drained papal resources already depleted by loans to England and France. Petrarch coments to Stefano Colonna on the relgning chacs in Italy.

Cisalpine Gaul, Indeed all that lies between the Alps, the Apennines, the Rubicon--the boundary of encient Italy--all chis vast region is oppressed by an undying tyranny aud that part of $1 t$ that looks to the west has become-oh hateful fortune-a thoroughfare for transalpine tyrants. So 1t 1s, therefore, that nowhere in this region can you find a place where a lover of vircue and of tranquility may live in quietness. Tuscany today, her footsteps faltering between a doubtful liberty and a jreaded servitude, knows not what her fate 18 to be.

Petrarch did not see the Italian situation as a territorial struggle between tyrannies and repub11c8. "A lover of virtue and tranquility," Petrarch advocated an end to polftical disorder by any means.

Petrarch and most Itallans regarded the Avignon Popes whth extreme suspleton. All popes from Ciement $V$ to Urban V were Freach, as were 113 of 134 cardinals chosen by them. In response to the sandalous financial practices and divisive Italian pollcy of the papacy Fetrarch mote hla Letters Without Names (S1ne Nomine). Moat ${ }^{88}$ Petrarch, Petrarch at Vaucluse, p. 98, Pam111ares XV, 7 (1352). 
of the nineteen were without specific addressees. Because of their

blatant political and anti-elerical tone they wers closeted until

Petrarch's death. The introduction spells out this necessity.

I have brought together in one collection several letters wicten to my friends for diverse wotives and at different times, frow fear that being scattered about, thej wight becose a blot on the entire body of my letters and so render them hateful to the enextes of truth. They will be released after I an gone for wat difference will ic make then how it ixritates them? ${ }^{89}$

The Letters Without Names went only to close friends winose sympathy wth Petrarch's views was assuned. They were accompanied by a plea to read and return thea to the writer's safe-keeping. Petrarch knew well enough that the "enentes of truth" controlled the ecclestastical Income he depended upon.

One of the main targets of Petrarch's distribes was Clement VI. Clewent set up the most wagnificent court of the "Babylonian Captivity," squandering wealth on the papal palace and the purchase of the city of Avignon from Naples in 1348. Petrarch's characterization of the pope was not subtle.

Here In Avignon 18 Nigrod [Pope Clement VI, who was fond of hunting], bullder of turrets, and at the same tiwe sower of dread; here there is Semiramis [Viscountess cecilia of Tureane, the mistress of the Pontiffl, arned with a quiver. 90

Petracch was not an activist or a political pamphleteer. It was natural, however, that he express his frustrstlors to friands in a

${ }^{89}$ Quoted by John E. Urigley, "A Papal Secret Rnown to Petrarch," Speculua, XXXIX (October, 1964), P. 615.

90Quoted by Mario Emilio Cosenza in Francesco Petrarch and the Revolution of Cola di Rienzo (Chicago: University of Chicago Press, 1913), p. 145, Sine Nomine viII (1351-52). 
manner that could bring no retallation.

Petrarci wrote the life of Solitude fu 1346 as a gift for his dear friend Prtllipe de Cabassoles, Bishop of Cavafilon. A comendiua of personazties whose love of solftude brought them firtue and glory. the Liff of Solftude is called the "major document of Petrarch's later humautss" by Hans Baron. 91

The stated goal of the work was to prove that scholarly withdrawal was nore virtuous and productive than the active 11 fe. Petrarch's ideal is not ascetic. He states "Let man's leisure be modest and gentle, not rude; let his solitude be tranquil, not savage; In ahort, let it be solitude and not barbarism." 92 The search for God is only secondsry to Petrarch. The frults of the scholarly life are not a peaceful contemplacton of the spirit but an active part in the restoration of ancient wisdom.

To move about at wi1l and converse with all the glostous men of the past, to lose consclousness of those who work evil in the presest: somerites to rise, with thoughts that are lifted above yourself, to the ethereal region, to maditate on what goes on chere and by meditation to inflame your deafre, and in tum to encourage and admonish yourself with a fervent spirit as though wth the power of buraing wordo-these are not the least important frulta of the solltary life. Let not pass over in silence, however, the more obvious pleasures: to devoce oneself to readIng and witing, altemately finding employwent and relief in each, to zead what our forerunners have written and to write what later generations may wish to read to pay to posterity the debt wich we camot pay to the dead for the gift of their writings. 93

91 Hans Baron, "Petrarch: His Inner Strugzies and the Humanistic Discovery of Man," In Florilegiun Historlale: Essays Presented to Nallace K. Ferguson, ed. by J. G. Rowe and W. H. Stockdale (Toronto: University of Foronto Pres3, 1971), p. 35.

92 Petraxch, Life of Solitude, p. 162 .

93 Ib1d. P. 150. 
Central to Fetrarch's presentation of the life of solitude is ar wapoken conflict between the active and contemplarive life. Petraxch once considered writing a companion rolume on the virtues of the astive 11.fe. He could have used the heroes of the life of Solitude to justify civic involverent. It is after all, hard to picture Julfus and Auguarus Caesar, Pompey, Alexander, and Clcero as celebrants of withdrawal from society. Petrarch ignores the Sciplo of his Africa and sakes his argue for a truth be would not have accepted. Scipio, funior and serior, the two thunderbolts of war became, in the life of Solitude, conkented beachcombers. Petrarch says

Ob excellent spectacle, transcending the powp and scepters of all kings, to see such men, the preservers of the State, the 1iberatore of the citizens, the defenders of Italy, the conquerors of nations, their task successfully performed, the victorious people dismissed free and rejoicing . . . their triumpal habit put off, strolling alone, at laisure, and unconsclous of depresing cares, over the hills and along the shore, and often picking up little shells or sea pebbles of different sorts, both black and white. 94

In an equaly blatant distortion of Clcero's personality, Petrareh condems Clcero's plea for clole responsibility. Petrarch adaits,

Although he affiras that the active 11 fe 1 a sore profitable to the State, which is a measure even I will not deny, he admits thyt the retired 11fe is safer and easier, less burdensome and vexatious than other wodea of $11 \mathrm{fe}$, and therefore he not only sanctions it for those who have some fair reason for embracing it, but especially conmends it to those who excel in intellect and learning. 95

$$
\begin{aligned}
& 94 \text { Ib1d. . p. } 288 . \\
& 93 \text { Ib10. . P. } 278 .
\end{aligned}
$$


Petrarch conventently forgete that it is a Cicero exiled frov public office who writes this lament fron enforced solicude. Petrarch Ignores the historical cicero on principle. He knew that the orator belonged in the forum. Petrarch asserted, however, that cicero's eloquence should only have been used for philosophic ende.

The mixture of Biblical and Roman heroes in the life of Sollcude 15 not a fusion of pagan and Christian philosophy by Petrarch. Petrarch condems modern barbarlans wth wise words, both pagan and Christian. The lnstability of Itallan polltles, the devastation of the Hundred Years War, and Eaperor Charles IV's lack of spirtt kept the Christlan world from winning back the holy lands. Petrarch admonishes contemporary rulers

If Jullus Caesar should come back today frow the lower regions, bringing with him his former splrtt and power and 1f, living in Rowe he should acknowledse the nawe of Christ, as he doubtles: would, do you think that he would any longer suffer the Egyptian thief to possess Jerusalem, Judea, Syrian, Egypt, and Alexandr1a? 96

Petrarch usea Caesar as a rhetorlcal model. Knowing that the name of Caesar implied the qualities of strength and w11 to power, Petrarch ansumes the readcr w111 contrast this to the nodern 1 ack of initiative.

Petrarch's interest is poltetcal affatrs to related to his historical coacero with the heroes of Rowe who led her to greatness. E1s political. ideals were not based on workable theories drawn fron Roman history. Petrarch had naive falth in the power ef Individual polltical action to transform reality.

96 Ib1d., p. 246. 
Cola di Rlenzo was an ambitlow young norary, well-read in the traditions of Rose and eloquent in his call for the reinstatement of a true republic. Cola lived in an anciquarian fantasy in order to escape mundare notarial activities. On May 19, 1347, supported by "legtons of the Roman people," he took control of Rome. In Cola's short-lived republic an antiquarian clisste peraeated the ciey's government. It found expression in Cols'a asgurption of the title "Iribunus Augustus" and his bathing in the font comonly telleved to have been used to cure Constantine of leprosy. 97

Cola restored order to the city, created a popular militia, Instieuted strict eax collections and a soctal velfare program, and called an Italian parliament to consider reunlon of the Empire.98 Clement VI, however, oaw the danger in Cola'g uourpation of power Whout papal permission. Cols aggravated the situation by declaring he was acting under the Inspiration of the Holy Ghost. He also described Clement as a "madman and Insane, suspect of schism and heresy." 199

Petrarch on the other hand, was imediately taken with Cola's statement of purpose. He admits, "I was especially enamoured of his virtue; I applauded his design and admired his spirit; I congratulated

97 Robert Hels8, The Reneissance Digcovery of Classical Antiquity (Rew York: Humanit1es Press, 1969), p. 41.

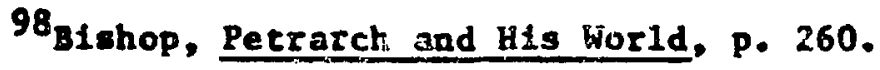

${ }^{99}$ Quoted by Mollat la The Popes at Avignon, p. 148. 
Italy and anclcipaced a reacoration of dominion to the mother city and peace for the whole worid $n 200$.

Petrarch places Cola In direct auccesaton to the long line of

Roman civil and military hezcea. Here, a elsewhere, Petrarch uses

hiscortcal facts the corically:

O thou younger Brutus, keep ever before thine eyes the exemple of the first Brutus. He was consul; thou are tribune. If ve should compare the two offtces, it vould be found that the Consule performed acts hostile to the walfare of the Roman plebs, but the Tribunes were always and constantly che defenders of the people. . . Hall then our Camillus, our Brutus, our Rowulus! The present age owes it to thee that it $\$ 11$ die in liberty; to thee posterity will owe that it is conceived in liberty. 101

The revolution of Cola is the sole example of Petrarch's support of a republican regine. This ia the firat and only time Petrarch applies the Roan language of liberty to fourteenth-century history. In addressing the Roman People, he goes 00 far as to condem his patrons, the Colonna, for their oppresstion.

Drive from your hearts the 111-deserved love which through a long subjection, you may have concelved for your cyrants... . Oh illustrious citizens, you have teen living as slaves, you whom all the nations were wont to serve. Though kings we re wont to kneel at your feet, you have been passive beneath the eyranny of a few men, strangers and lords of foretgn lands who have falsely ceclared themselves komans, 102

Cola's pretentious statements gave Petrarch a sense of security. His use of the tradftional gestures of antiquity was as important to

${ }^{100}$ Quoted by Robinson in Petrarch, p. 343. Faniliares XIII, 6 (1352).

101 Quoted by Cosenza in Petrarch and the Revolution of Cola, p. 35. 102 Ibld. . p. 19. 
Petrarch's historical lagination ss it was to Cola's ego. The

Church did not appreclate cola's intent to "begta anew the annals of Roxe."103 The papacy demanded an oath of fealty and Cola refused to give one. Folloring a loss of confldence by his nobles and aental breakdow, Cols was deposad in December of 1347. Petrarch comented 1mediate1y.

I fear that thou no longer, as formerly, lovest the whole people but only the worst element. Shall the world behold thee, who hast been the leader of patriots, bacome the accomplice of reprobates? Glory is imortal; imortal, too, is infamy. If Cola has no thought for his ow reputation, let hid at least think of Petrarch's. Cola must knos what a atorm hangs over Petrexch what a croud of reproachers will assail him if Cola fa11. 104

Cola's sudden demise shocked Petrarch, who had no knowledge of the difficulties attending the creation of a new republic. Petzarch had Inaglnatively envisloned himself as the poet laureate of the resurrected Rose. However, he places the blame less on Cola than the vickedness of hia times. He says in a letter "To the Roman People, urging then to intervene In Rienzo' trial,"

The uprewe crime with which he is charged and which wertis explarion on the scafiold is that he dared afflrm that the Rowan Enplre is still at Rowe, and In possession of the Roman paople. Ob Implous age! Oh preposterous jealousy, malevolence uprecedented. 105

103quoted by Robinson"In. Petrarch, p. 341, Epistolae Varine XIVIII (1347). p. 187.

104Quoted by Cozenza In Petrarch and the Revolution of Cola,

${ }^{105}$ Quoted by Robinecn In Petrarch, p. 349. 
The political fragmentation of fourteenth-century Italy makes It Iopossible to concelve of a ruler strong enough to weld the broken empire back together. It was Cola who was implous in his bellef that the pactfication of the clty of Rose could be extended to the whole wor1d.

After the fallure of Cola, Petrarch again advocates monarchical over republican institutions. The tone of Petrarch's utterances on Caesar is transformed. In Letters Hithout Names, IV, Petrarch admits, "It Is a positive fact that, even after the tyranny of Jullus Caesar (or monarchy if we so prefer), the Roman emperors sought banction for their deeds either from the senste or from the Romen people."106

In 1348 the Black Plague swept through Europe, k1111ng half the population of Avignon alone. Laura was cnly one of many who died. Petrarch complains "I am not mourning sowe slight distress but that dreadful year 1348 which not merely robbed us of our friends, but robbed the whole world of Its people."107 The melancholy Triumph of Death emphasizes the swift and unexpected blow of Fortune. In a volce reminiscent of Augustine in The Secret, Petrarch inquires,

Where now are their riches? Where theit honors now? Where now their gems and scepters, and their crowns, their miters, and the purple they had worn?

Wretched who sets his hopes on mortal thingsYet who does not? and $t$ he finds himself deluded at the last, it is but fust. 108

${ }^{106}$ Quoted by Cosenza In Petrarch and the Revolution of Cola, p. 282 (1352).

107 Petrarch, Letcers from Petrarch, p. 73, Familiares VIII, 7 (1349). 108Prancesco Petrarch, The Trtumphs of Petrarch, trans. by Ernest Hatch Wlikins (Chicago: Univergity of Chicago Pres8, 1962), p. 56. 
The Triumph of lame ts an encyclopedic processton of Christian. classical, and modern figuras who won etemsi glory through military or 11terary skills. First in line were Petrarch's two favorite heroes.

At her [Fame] right hand, where first I bent ay eyes were Sclplo and Caesar: but which one was closer to her I could not discern. 109

In this final veraion of the Triumph of Iane, Sctpio and Caesar stand equidistant frow the goddess. Guido Martellotti has shown, however, that "In the firat draft of the Trionfo della Fama wrten shortly after 1350, Cacbar obscures Scip10's figure because he stands resplendent at Fama's right, whereas Scipio is merely one in a crowd led by hugustus and Drusus." 110 We have seen Petrarch use both Sclplo and Caesar as historfcal models. Cola's fatlure and Perrarch's loss of falth in republics in general explain the priority of caesar in 1350.

Petrarch shows his poor opinton of the "modern" age by listing only two medieval heroes, Ring Arthur and Duke Godfrey.

Few wen, If any, saw I after thew rise to high fame, if I be not decelved efther through arts of peace or arts of war. 111

The "Ascent of Mont Ventoux," Familiar Letters IV, 1 is dared by Petrarch "on the twenty-81xth of Apr11 1336." It Is not probable that thls long letter was written the day of the exhausting climb. The "Ascent" relterates the themes of the "Secretum crisis" of 1342-43. ${ }^{109}$ Ib1d., P. 74. ${ }^{110}$ Quoted by Baron in "The Evcluetion of Petrarch's Thought," p. 29. 111 Petrarch, The Trilughe of Petrarch, p. 84 . 
B11lanovich ssserts that Petrarch chose the yeas 1336 for 1 t8 symbolle value. In this fear Petrarch would have been exactly the age of Auguatline at the time of his conversion. 112

Petrarch's brother Gherado, a Carthuslat ronk, is his companion. With litele trouble the mork climbs directly to the top of the peak while Perrarch "wandered theough valleys, looking for the longer and easie: path and stumbling cnly tato longer difficulties."113 on attaining the sumit, Petrarch pauses to reflect on his wicked life. He realizes that it is ten years to the day since he left school in Bologra, and he 18 still almost as corrupt as in hie youth. As he was about to start his descent, despairing over his lack of progress, Petrarch fatefully looked Into Augustine's Confessions.

It 18 a little book of smallest size but full of Infinite sweetness. I opened it with the intention of reading whatever night occur to me first: nothing, indeed, but plous and devout sentences could come to hand. I happened to hit upon the tenth book of the work. My brother stood beside me, intently expectIng to hear something frow Augustine on wy mouth. I ask God to be my utrness and my brother who was with me: Where I fixed my eyes first, it was written: "And men go to admire the high mountalns, the vast floods of the $8 \mathrm{ea}$, the huge strearas of the rivers, the circumference of the ocean, and the revolutions of the stars-and desert themselves. 114

Petrarch belleyed that Augustine's words were meant for him alone, directud at his degenerate spiritual state. Petrarch decided to Intermalize this admonition and dedicate himgelf to religious concerns.

\section{Referred to In Baron, "The Evolution of Petrarch's Thought," p. 18.}

113 Francesco Petrarch, "The Ascent of Hont Ventoux," In The Renalsgance PhIlosophy of Man, ed. by Ernst Cassirer, Paul Oskar Kristeiler and John Herman Randall, Jr. (Chlcago: University of Chicago Press, 1948), p. 39.

114Ib1d., P. 44. 
The actual climb, however, alrectiy preceded Retrarch'e inttial work or Afrlen and The L1ves of IIIustrious Men." The spiritual "ascent" of Hont Ventoux is an outgrowth of tho "Gectetun eriati." Thts was the first time that Christion guilt-pangs had any real effect on Petrarch's 11fe.

In 1351 Pecrarch prepared to leave Avignon and Vaucluse forever. He sent wessengers to Italy to get informetion on possible restdences. H1 final destination undecided, Petrarch stopped first in Milan In 1353. He received an fnuttation from Archbishop Giovanal Visconfi and stayed in the lombard capital for eight productive yeara. Petrorcis choice dismayed both his friends and subsequent biographers. His seifprofessed love of solltude and hatred of tyranntes showld have led him last of all to Milar. Bergin remarks; "The largest city in Italy seemed a rather lnappropriate residence for a hermit, the vtscont vere despots, and thelx southuard driwe had already made them enemles of the Florentine Repub11c."115

In 1352 Petrarch declined an invtation, Issued at Boccaceto's urging. to gettle In: Florence. Although Pètrarch occastonally called it bts "Patria," "he seems never to have forgiven Florence for the extle of his parents and confiscation of his petrimong."116 Petrarch wanted to ensure his 11 terary freedow and easily ignored the criticisas of his republican friends.

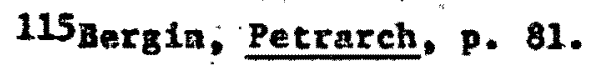
116 Wilkina, Petrarch's E1ght Years in Milan, p. 4. 
Petrarch was supported by so-called tyrants throughout his iffe. His ataittediy close friends Robert of Naples, Azzo da Corregte, and Jacopo da Carrara were not renowned in the Trecento as civil 1 ibertarlans. Glovant Pisconti prowised and provtded Petrarch with solltude in the midat of the expanding elty-gtate. Fetrarch nevertheless felt obligated to occasionaliy accept diplomatic missions on behalf of his patrons. To Boccaccio, his most concemed friend, Petrarch Justifled his reaidence.

Wherever I may be, I shall try to keep ary thought free, even though I may have to submit to superiors with regard to my body and external circustance-Whether subsitting to one person, as I do, or to many, as do you. I think it is easier to bear one man's authority than that of a tyrannical populace. 117

A further coment on Petrarch's scate of mind is his letter to the Genose Doge in 1352. An surocratic reglme had been established in Genoa after a long perlod of civil war. Petrarch endorsed this solution. "Eventually, warned by these evils you took refuge in the help provided by the rule of one just leader, which is the best condition for the comonwealth beyond any doubt." 118

Charles IV of Bohenla waa elected Holy Roman Emperor in 1346 after the deposition of Louls of Bavaria. Once again the papacy had an elly in Italy. Learaing from past aistakes the popes supported Charles only on condition that he

annul Ienry VII's proceedings sgairst Robert of Anjou, Rome and Floreace, revoke all acts of Louls of Bavaria and respect

117 Ib1d., P. 8.

118 Quoted by Baron in "The Evolution of Petrarch's Thought," p. 36, Fand11ares XIV, 5. 
8olden wan, measurirg his opportunttles th the light of his resources, eminenty cautious, his feet fimly planted in the eoll of reality." 122 Charles answered Petrarch's letear very prectlcally, pointing out that the polictes of Scipio and Caesar offered no guide to fourteenthcentury poiltica. The desperate condition of Italy wade effective imperial action all but fmposible, and the gize of a reconstituted zaplre wonld make it ungovexnable, 123

Betweez October of 1354 and June of 1355 Charles was in Italy on Invitation from Pope Clement VI to recelve the limerial crown. Fetrarch met with Charles In Mantua and recorded the conversation with great enthuzlasm and no little 1magination. Petrarch advised Charles on future polftical sctions and naturally talked about his om "modest" talents.

The impertal conversation descended to an everyday level, he even asked me about oome small works of my own, espectally sbout the one I have entitled De Viris Illustribus. I tolk him that it was unfinished and that I needed more leisure time to complete it. When he asked me to send him a copy later, I answered with the frankness I comonly ube towards eminent men. (It is natural but ft geems to be increasing with time, and will be gigante when old age arrives.) 'I proulse you a copy.' I said, 'If your virtue persists and ny life too." He was surprised and asked my meaning. 'As far as I am concerned,' I sald, 'I need a lifetime to write such a big book, for it is very hard to treat great matters in a small sprce. And as for pou, Empezor, you will be warthy to recelve a book with such a title if you are to be numbered among the 111ustrious wen not by uide reputaction or any meaningless diadems, but by your deeds and by

122C. C. Bayley, "Petrarch, Charles IV, and the 'Renavatio Inper11." "Speculum,XVII (July, 1942), P. 326.

123 wilkins, Petrarch's Eight Years in Milen, p. 44. 
noblitty of gptrit, and if you so live that posterlty may read of you as you read of the great ancienta. 124

Much to Petrarch's dismay, the coronaticn of Charles in Rome did not iead to his dolng great deeds in Italy. In agreement with his promise to Clement Charlea withdrew Imediately to Germany. Petrarch writes to Charles in Prague.

If your grandituther and father should meet you on the Alps, what do you think they would say to you? I belleve you can hear them speaking, even though they are not there: "Most nobly hast thou wroughe, oh great Caesax, in thy long-delayed entrance into Italy and thy hasty retreat! Thou bringest wich thee crowns of 1 ron and of gold and the sterlle nave of emplre; thou nayest be called Emperor of the Rcmans-thou art in truth ring of Eohemia and nothing more.:125

Charles had accepted the title of Emperor Iu order to gain papal support and Irallan revenue. He wanted no outside Interference in Germad poliefcs and thus had no latention of costly involvement in Italy. Petrarch did not undargtand Charles' motives. A romantic Idealist, Petrarch would not hava changed the style of his appeals even with knowledge of the facts.

Charles continued his correspondence wt th Petrarch but so longer asked hin for political advice. The growth of Prague as a cultural center and the need of a "gtar" name induced Charles to ask Petrarch to move to his court. 126 Petrarch refused but did provide the Experor wth important evidence of forgery in two documents eupposedly written by CseBar and Nero. These forgeries produced by

124Quoted by Bergln in Petrasch, p. 35, Famtliares XIX, 2 (1354). 125Quoted by Wilkins in Petrazch's Fight Years in Milan, p. 98 , Pan111ares XIX, 12, (1355). P. 334 .

126Bayley, "Petrarch, Charles IV, and the 'Rezavatio Imperdi," 
Rudolf VI of Austria would have exempted certaln territories froa Charles" rule. The simpliexty with which Petrarch dissects the documents reveals both a critica: atnd and a great faulisrity with the cultural and legal tradictons of Roue. Petrarch'a intrate knowledge of the forta of anclent Latin let him discount authenticity on scylo alone.

The date of the documeat 1a clearly false. It does not indicate the exact day, nor the consuls in office. Only an idiot would say 'given at Rowe on Frlday in the first year of our relga' without adding the month and the day. What shepherd, what ploughman would wite like chtsw-let alone the man who had, besides his other great deeds, reformed the calendar. Then he says of our relgn, which is 80 far from the truth as to arouse indignation as vell as laughter. For, as you have heard, Caesar wished to be called 'general,' 'pontifex,' ano 'dictator'--never 'king.' Ke read that Rome in earllest times had saven kings. Those who wiahed to becone kings after this were put to the sword or throwr from the rock on the Capitol hill. I adrit that Cacsar was suspected of wishing to he 'ingerbut only by his enemies. He was too prudent and too careful of hig reputation to take a title which would have made him infamous. He wovld no nore call htoself a 'king' than 'buffoon,' 'adulterer,' or 'plmp.' In fact he was even less likely to allow $1 \mathrm{t}$, for whlle the other names are shameful and filthy, that of " $k$ ing" was odious, dangerous and intolerable at Rome. 127

Petrarch's sensitivicy to style and IInguistlc evolution must not be equated with his historical sirareness. This etatement is proof that Petracch could be a critical philologist when he vented to be. However, he was rarely asked to do such practical work. In most lngtances, Petrarch's didactic goale demanded that he atretch his historical sease by ustng facts rhetorically.

127Quoted by Burke in The Renaissance Sense of the Rast, P. 53, Sendles XVI, 5 (1361). 
Petrarch's only osher contace wh Charles sas in 1367 . The Buperor accompanted Urban $\nabla$ on the papacy'g geentn to Rome from Av1gaon. Petrarch was ovexjoged and chought the Christian Eapire had been reimstated. The revtyal of the clasalcal nodel did not atrad. Wthin three years the pope had recurned to Avignon end Charles was again in Prague.

In 1361 Petrarch declded to make a collection of his later letters, The Letters of old Age (Seniles). Just as he had closed the Fantllar Letcers with letters to anclent men, Petrarch ended chese wth the "Letter to Poster1ty."128" This letter revives one of

Petraxch's faworite theses, his shift from profane to sacred 1tterature. He coments

Hy wnd was rather well balanced than keen, adept for every good and wholesome study, but especially inclined to woral philosophy and poetry. I neglected poetry in the course of time, finding ay pleasure In sacred itterature wherein I discovered a hiden areetness which I had previously despised, and I cane to regard poetry as merely decorative. 129 .

Here for the first time Petrarch accepted a medieval definision of poetry as oxnamentation. As we shall see, this denigration of poetry extendec beyond Petrarch's personal work. It was his fustiflcation to Boccaccio for Indifference to Danze's Divine Coredy.

Petrarch explalned his love for Latin literary and historleal works in teras of the poverty of his age.

128 wilkins; The life of Petrareh, p. 246. (1353).

${ }^{129}$ Petrarch; Letters Erom Pettarch, 9. 5, "Eptatle to Posterity," 
I devoted nyself, though not exclusively, to the study of ancient times, since I always disliked our own pertod; so that, if it hadn't been for the love of those dear to we. I should have preferred being born in any other age, forgetting this one; and I always trled to transport ayself mentally to other times. Thus I have delighted in the hiscortanc, though troubled by their disagreerents. In case of doubt $I$ dectded either according to vertsinilitude or the authority of the uriter.

The Letters of old Age was dealcated to Francesco lielli, a Florentine man of letters aid friend of Boccascio and Petrarch. By 1374 it coratated of seventeen books, containing a total of 127 letters on a grest varlety of topics.131 In a letter to Boccaccio in 1365 Petrarch utilized the tools of philology to verify historicel evidence. In his attempt to discover the age of the city of Pavia, Petrarch finda that it cannot be daced earlier than the Second Punlc Har. "Even in conection with that period Livy only mentione the river and not the town. However, the olmilarity of the nasegmethe river 'Ticlnus' and the town 'Ticinfun'--aight easily lead to the confusion of one with the other." 132

Petratch always considered hinself the most orthodox of Christans, but he refused to accept the "prophetic revelation" attributed to Virgil in the BAddle Ages. He was equally suspicious of Christian wracles. Morris Btahop only sllghtly overstares the case when he aees Petratch blanisg the stignata of Saint Francis on "auto-suggegtion or traumatic poychosis."133 In Letters of old Age VIII, 3 Petrarch

\section{auggests}

130 Ib1d., p. 7.

131w11kins, The Life of Petrerch, P. 246.

132quoted by Robinsors in Petrarch, p. 322, Sen1les $7,1$. 133Btshop, Petrarch and His World, p. 354. 
His meditation on Christ's desth was so intense, his aind was oo occupted with 1.t, that it seemed to hit that he vas crucified wth our Lord. Thus the force of that thought could pass frox his mind to his body and leave the visible traces impressed upon $1 \mathrm{t} .134$

Petrarch's two lettera to Nelli reflect the continulag debate between his love for the ancients and its conflict with Christian trath. The work of BIIlanovich and Ullman has eest doubt on the author'a conteation that his youth was devoted to the classics alone. On this assuption, Petrarch asserted that his Auguetine-styled religioug "conversion" of 1342 introduced hib to sacred 11tersture. Petrarch says

Let we speak of myself and my new but serious enthusiasm, which turns my thoughts and my writings, to sacred 11.terature. Let the supercillous laugh, who are revolted by the austericy of bold words, as the modest garb of a chaste watron repels those who are used to the flactering colors of light wowen. I think that the Muses and Apollc will not berely grant we permisaion, they w111 applaud that ater giving woy youth to studies proper to that age. I should devote wy riper years to moxe important sarters. 135

We would not deny that The Secret and the "Ascent of Mont Ventoux" are the results of this devotion. Petrarch, however, concludes this same letter in a different tone.

But although I put the Christian vriters firse, I do not refect the others. (Jerome said he did 80 , but it seems to we from the inftative style of his writing that he actuslly approved them.) I seem able to love both groups at once, provided that I conselousiy distinguish between those I prefer for atyle and those 1 prefer for substance. 136

134Quoted by B1chop in Petrarch and His World. F. 354 , Sentles VIII, 3 (1367).

135 Petxarch, Leters from Petrarch, p. 190, Faniliares XXY, 10 (1.358).

${ }^{136}$ Ibld. P. 191 . 
The mixture ef Christians and classical figurea in the Lives of

Illugtrious Men, the Life of Solstude and the Triumphe is evidence

that Petrarch loved both groups sixultaneously if not equally.

Petrarch implles that the classical authors should be initated solely

for their style. They lacked the Christian religion which alone could give erue "gubstance" to scholarship. As often as not, however,

Petrerch does not consclously distinguish between the two groups on

these teras. Petrarch pleads in val.a that he no longer passionately

loves or reads the ancients. We find hin defending the Christian

1mplications of Cicero's bellefs in 1358.

I am not afraid of being considered a poor Christian by declaring myself so much a Clceronian. To my knowledge, Cicero never wrote one word that would conflict with the princlples proclaimed by Christ. If perchance his works contain anythiag contrary to Christ's doctrine, that one fact would be anfficient to destroy my beliaz in Cicero, and in Aristotle, too, and in Plato.... Cicero frequently wakes wention of the gods, following the custom of his times. He devotes an entire rolume it is true, to a discussion of the nature of the gods. If you read beneath the surface, however, you will be convinced that he does not so much pay honor to this throng of gods with their empty names, but rather exposes them to ridicule. Where he seriously expresses his own opinion Cicero asserts that there is but one God and he 1s the Prince and Ruler of the universe. . . Christ is my God; Cicero on the other hand is she prince of the language I use. I grant you that these ideas are widely separated, but I deny that tieg are at conflict with one another. Christ is the Word, and the Virtue, and the Wirdcr of God the Father. Cicero has wrftten wuch on the Epeech of wen, on the virtues of men, and on the wisdon of men-skatements that are true and therefore surely acceptable to the God of truth. 137

Petrazch is his unhigtorical best in this statement. He must read hidden meaning Into Cicero's vorcis to prove him a pagan in nase only.

137 Petrarch, Petrarch's Letters to Claseical Authors, p. 18,

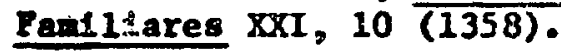


In other Instanceg Petrarch refused to conderin the ancients because they were born into an age igncrant of the true religion. Here be asserts that their wisdon and comon sense did not conflict with the ethical precepts of Christianity. Petrarch was only the first of wany scholars to deny that pagan lizerature was dangerous to Christian belief. Clcero's fusion of eloquence and wisdon sas a positive gulde to virtue, one of the many routes acceptable to the God of truth. Petrarch used Latin exclunively in his major works. He refused to use Italian even in everyday letters to friends. A serious subject denanded sutable expression. Petrarch believed that the latin language eabodied the virtue of Rowan civilization. In h1s old age, Petrarch Elnally revealed his antipathy toward Dante and the vernacular. Responding to questions from Boccaccio, Petrarch confims the superlority of the Latin tongue and thus indirectly criticizes Dante's purpose and style.

Latin is of course the loftier language, but tt has been so developed by ancient geniuses that neither we nor anyone else can add much of anything to 1t. The vulgar tongue, however, has only recently been formulated. It has been mishandled by an: and tended by only a few; rough as it 1s, it could be much beautifled and enriched, I am sure. Inspired by this hope and filled with youthful ardor. I once besan a magnum opus in Italian. I lald the foundations, as of a bullding, and collected the lime, szcne, and wood. And then I observed our age, the mother of pride and sloth, and I began to reflect sourly on the power of the stug critics and on thetr charaing pronunciations, such that they mut1late whatever they read. Hearing their performances again, I thought and concluded that my strueture rould be swallowed in soft wud and quicksand; I should see wyself and all work mangled by the mob. . . I no longer regard then as alne but rather the property or the general public. 
I. shail take care that wy wajor works shall wot be similarly lacerated. 138

The most succinct statesent of the conflict between latin and the vernacula: 13 given in Fanileter Letere XXI, 15. Boccaccio, overwhelrad by the poetic genlus of Dante, had written to ask why Petrarch did not own copy of the Divine Cossedy in bis youth. Petrarch's response reveals more than distaste for Tuscan speech.

Such was my self-confidence and enthusiasm that I deemed ay own powera quite sufficient, whout any portal aid, to produce an original. of ay own. It 1 for cthers to judge whether I was right in this. But I must add that if angthing should be discovered in my Italian vritings resembling, or even Identical wth, what han been sald by him or others, it cannot be attributed to a secret or unconsclous initacion. - 39

Petrarch goes on to give Dante, the "prince of our vernacular," another backhanded compliment.

What probability is there that I should be jealous of a writer who deroted his whole $11 \mathrm{fe}$ to those things which with we vere but the flower and firat-fruits of my youth. What to him was, if not his only occupation, certainly the supreme object of his life, to ne was mere sport, a pastime, the first essay of wy powers. 140

Petrarch belleved that because the Divine Comedy was witten

1t Italfan it was directed to the coumon herd. The high-flown Latin

In his Africa would be appreciated only by the truly knowledgable.

Far fron destring such popular reccgattion, I congratulate waelf, on the contrary, that, along with Virg 11 and Homer, I an free from $1 t$, in as much as I fully realize how little the plaudits of the unschooled nultitude velgh with acholara. 141

138 Petrarch, Letters from Petrazch, p. 244-45, Sen1les V, 2 (1364).

${ }^{139}$ Quoted by Robinson in Petrarch, p. 183 (1359).

140 Ib1d., p. 186.

$141_{\text {Ib1d., p. } 183 .}$ 
Petrarch spent long years revising Africa and heard wuch negative coment from contemporaries on its style. To retionalize th1s, Petrarch adaitted that Africa was less popular than the Divine Cogedy. only because its purpose was too lofty.

Petrares gladly admitted his conacious fmitation of the ancieats. "I have read Vergil, Herace, ilvy, Clcero not once but a thousand tines, not hastily but dwelling on them. They are not only in my alnd but In wy marrow; they are pazt of myself." 142 A almilarity of goals rewoved the anclent poets from coapetition with Retrarch. Dante stood in too close proxintey, however, and had to be dealt with on a different level, Petrarch did not like the religious orientation of the Elvine Coaedy. In his thinking, great poetry should be written In Latia and deal with human problems. Petrarch did not adnit he was jealova of Dante's popularity. He crificized his ow Italien poetry as a "mere sport," Implying that, unlike Dante's, his mature work ves trulg gubstantial.

In 1361 Petrarch began The Deeds of Caesar. Originally one of the 24 Roman blographles of The Lives, Petrarch later considered it a separste voric. 143 The fallure of Cola's republican revolt and a renewed concern with the Roman Eapire through the offlce of Eaperor Charles IV led to Fetrazch's late interest in Cresar. Friedrich Gundolf comencs,

${ }^{142}$ Quoted by B1shop in Petrarch and Hia World, p. 373, Familiareo XXI., 2 (1359).

143w1kias, Petrarch's Later Years, p. 287. 
Caesar was unquestlongbly esthetlcally broader and rlcher, hiscorfcally more declstue and more comprehensive, more trmense in his were volume of deeds and their scope, the degree of his greatnesa and, at least for the age in which Petracch grew to nanhood, more celebrated, more glorlous than Scip10.144

The Deeds of Caesar is a critical compllation from Caesar's

Comancarles on the Gallie Vars, Suetonius and other Latin historiane.

That Petzarch did not attribute divine origins and legendary herolcs

to Cacsar probably grew out of his understanding of the aources.

The Comentarles are the memoirs of a comander, and the Letters $\leq 0$

Atricus are Cicero's perceptions of Caesar's polltical ambitions.

It wat the personality of Caesar that Intrigued Petrarch, not his

office or the founding of the Emplre. These had been central to the

medieval perception of Caesar. Gundolf asserta that

The fase of Caear in the modern sense begins in this blography; It is no longer associated with sacred offlce or an allegorical sigatficance, or a magical sound, but yith the knowledge of great deeds, and the emulation of high manhood. 145

The shift frow Caesar as tyrant to Caesar us hero is evident

In The Deeds, the lecters to Charles IV, and In an Inserted portion

of The Secret. Brutus, who had served Petrarch as a model of republican Irtue, now became one of the "trattorous heads of that conspiracy for whom Cacsar's Inexhaustible munificence proved too small to satisfy their rapacity." 146 Petrarch'a rellgicus crisis of the $1340^{\prime}$ a played a part in changing his attitude toward Caesar. Baron states, "The

1446undolf, the Kiancle of Caesar, p. 130.

$145_{\text {Ib1e. . p. } 132 .}$

146 Petrarch, Petrarch'g Secret, p. 95. 
De Civiatace Def had eried to expone the viclous note of egotstic ambition and thirat for glory in those who resisted and k11led Cresar."147 Petrarch's view of Caesar gradually changed through h1s readings of the Comentaries and the Letters to Atticus, both of which had been lost in the Hiddle Ages. A letter of 1367 , howevex, st111 reflects Fetrarch'o conaciousness of the dusl role Caesar could be made to play. "You remember the story of Cassius, one of the audacious wurderers of Jullus Caesar. (I von't call his inplous and criminal, to avold involvement in a question chat is 8 till in dispute.)"148 The Quattrocanto condemed Petrarch's adulation of Caesar as medieval, just as they did his characterization of Clcero. However, Petrarch 1s no longer blinded by medieval legends. He stands with the cicero of the Letters to Atticus, awed by the brilliance of Caesar's form, the Victorlous conqueror, orator, and author.

In 1367 in response to an "attack" by four Venetian Ariatotelians, Petrarch wrote the treatise, "On His Own Ignorance and That of Many Others." Hans Nachod remarka,

Be was then the most renowned scholar and moral philosopher of his age in the entire Hestern world. It came therefore as a severe blow to him to learn of a disparaging coment on his importance pronounced by persons he believed to be his friends and ednirers.149

The treatise vas not composed in anger but after a years' reflection on his frlendg" "short final sentence: I a good nan without

147 Baron, "The Evolution of Perrarch's Thought," p. 38. 148 Petrarch, Lettere from Petrarch, p. 258, Senlles VIII, 3. 149 Prancesco Petratch, "Ca His Own Iguorance and That of Many Othera," In The Renaissance Philosophy of Man, ed. by Emst Casalrer, Paul Oskar Kristellex, and John Herman Randali, Jr.. (Chtcago: Dniveralky of Calcago Press, 1948), P. 28. 
They used to ratise Aristotellan problem or a question concerming animals. Then $I$ was cither silent or made foke or began another subjecr. Sometimes $I$ salled and asked how on earth Aristotle could have known comething for which there is no reason and whlch cannot be proved by experience. They vere amazed and felt angry at in silence. They looked at me as though I were a blasphemer to requize anything beyond his euthority in order to believe ft. Thus we clearly ceased to be philosophers and exger lovers of wiscom and becane Arlatotelians. 153

Petrarch saw a difference between true lovers of wisdow such as Plato and Cicero, and Aristotle, the wost Influential philosopher of his age. This discontinutty was based primarliy on linguistic structure. Petrarch only knew the medleval version of Aristotle based on Arable translations. It was Arlstctle's "loss of eloquence" which separated him from his historical compatriot Plato. 154 Petrarch says

Aristotle teaches what vircue is, I do not deny that; but his lesson lacks the words that sting and set afire and urge toward love of virtue and hatred of vice or, at any rate, does not have enough of such power. He who looks for that will find it in our Latin writers, especiaily in Clcero and Seneca. 155

Petrarch used Auguatine to prove Plato's superiortey over Arlatotle in all wattera, especially in rellglous knowledge. Petrarch concludes his treatise not by questioning the philosophical assumplons of his Aristotelian friende but by justifying the tuperior wisdon of Plato and Clcero, his models.

of Plato, Augustine does not in the least doubt that he would have become a Chrigtian if he had come to life again in Augustine's time or had foreseen the future while he 11ved. Augustine relates also that in his time wost of the Platonists had

153Ib1d., p. 73.

154kancy Struever, The Language of H18cory in the Renalasance (Princeton, N. J.: Princeton Untveraity Presa, 1970), p. 95. 155petrarch, "On His Ora Igaorance," p. 1.03. 
becore Chrtstians and he hiwself can be supposed to belong to their number. If this fundamental stands, in what way is C1cerontan eloquence oppozed to Christan dogma? 156

It was on Plato's account that Petrarch attemped to waster the Greek langusge. He failed and although he owned a number of medieval translations, most of Plato remained "dumb" to him.

In 1367 Pope Urban $V$ returned the papacy to Rowe. Urban had been elected in 1362 and immediately set about reforming the Curia. He sent prelates in Avlgnon back to the benefices fron which they had absented themselves. He enforced simplicity of dress, patronized arelses and wen of letters, and supported the univeraities of Bologna, Orlears, Orviezo, Toulouse, and Paris.157 Erban gald a reunion of the Roman and Eastern Church would be posaible only if the Holy see returned to Rome. 158

The Freach cardinals did not epprove of Urban's decision. Their hostlity to Italy increased In the interse heat of Viterbo with no fine Freach wines to sustain them. The Vatican palace was in disrepalr, and the "unhealthy air" of Rome caused several cardinals to start back to France almost on artival. 159 The worst problem were the mereenaries who overran Italy and had to ba bought off yearly. Urbas was also forced to olga a hwillating treaty ulth Bernabo Visconti, a an he had earlier conderned as a heretic.

$$
\begin{aligned}
& 156 \text { Ibid. . p. } 115 . \\
& \text { 157wilkins; Petrerch }{ }^{\circ} 8 \text { Later Fears, p. } 54 . \\
& \text { 158 Mollat, The Popeg at Avignon, p. } 156 . \\
& 159 \text { Ib1d. p. } 155 .
\end{aligned}
$$


Petrarch was overjoged by Urban's eriuphant entry into Rome. He was too 111 to accept the Pope's invitation to join his court. Rumora of recurrent ansrchy in Rome and physical atcacks on members of tha Curia led Petrarch to vrlte, hoping to convince Urban to stay. It was already too late, however, as the Pope had fled to France. Urban excused hituself by saying he must return to where he could mediace the continuing struggle between France and England. 160 Petrarch's unfinished letter had personified Italy speaking to Urban of her 1lls.

I was wounded with mortal sores; you came to bathe my wounds and began tc pour in ofl and wine. And then, before my wounds were bound up or the balm had touched them, you left we. You had begun to cut away the rotten flesh with the steel, and then, cutting deeper, you perhaps found parcs thet aight have been healed. 161

Petrarch spent the last four years of his iffe in Arqua writing letters to frlends about his gradually falling health and his continuing literary work. His lagt major works, the Triumph of Time and the Triumph of Eternity were reflections proper to old age. Petrarch's theme is that the triumph of Time can only be destructive; that 311 mortal creations fall before it. Petrazch recalis the triumphant procession of Fame:

I saw fclk woving onward quietly, free fron the fear of time and of his rage, Histortans and poets guarding them. Chiefiy of these the sum was envious: for they, escaping from the comon cage, had mounted upward, Into soarting filght, 162

160 Ib1d., p. 160 .

161 Quoted by Wilkins in Petrarch'c Lacer Yearg, p. 133, Variac 3. (1370).

$$
\text { 162 Petrarch, The Triumphs of Petrarch, p. } 99 .
$$


Petrarch would not allow Tise a complete trituph. The function of poets and historians is to keep alfve the bezory of things past. His cwn death creeping ever clpser, Petrarch again proclatms that his words w11 11.ve os.

Petragch wrote the Triumph of Eternity during the last four months of his Iffe. Time's victory over Fane 18 refuted in Ecernity where the hum frame of reference is left behind.

Greatly I marveled, seeing time 1tself come to an end, that ne'er before had ceased, But inal been wont ip its course to change all things.

Past, Fresent, Future: these I saw conbined In aingle term, and that uachangeable: No swiftress now, as there had been before. As on en enpty plain I now could see no 'shall be' or 'has been.' 'ne'ex' or 'before' or 'after,' filling life with doubtfulness.163

The idea of an endiess present undoubtedly appealed to Petrarch. His celebration of love and glory would atand unquestioned. Posterity was to Petrarch a "1iterary" Heaven. He reflects further on this scate.

Future and Past, like hills that h1d out view, are levelled now, and nothing silil remains wherevgon hope or memory may lean,

Their varlation leading pen astray, thlaklog 'What have I been?' 'What ghall I be?' as if their lives were but an eupty gene.

The years no longer in the $1 r^{\prime}$ hands will hold the governance of sane: the glosfoys will glortous be to all eternity. 164

.163 IbLd., p. 108.

164 Ibld. . p. 110. 
Petrarch did not turn to the solace of religton in his final years. The Iriumph of Eternity does not uphold Auguselne's condemation of the "Cley of Man." Petrarch w111 have eternal fame because of his poetlc and historlcal crearions. He does not leave the world behind but carrles his wozk beycod the ravages of tise into the light of Posterity. 
CAAPTER III

CONCLUSION

By tracing the course of Petrarch's lite I have tried to expose the vartous factors bearing on his psychological development. His "exdle" froas Italy, early ochooling in France and Italy, and political and literary sssociations provide ws with the background. Analysis of Petrarch's 1fterary creations-the books and letters-allow us to see his hiatorical Imagination la action.

Petrarch gave ts many opintons on a wide variety of gubjects and 1t is out of these that we must cull his purpose. He did not write to an adoring pub1ic, He responded to questions of his intiwate ilterary circle, but it was to the "dutles" of a poet, historian, and zoral philosopher that he directed his energy. "Dreaming is the Singer's right" and it was toward didactic not aesthetic ends that his writing was directed.

Iw separate Petrarch from the medieval historlographic tradition we mast follow him out of the "C1ty of God" Into the secular realm. In the "Invective Against a Man who Spoke Ev1l of Italy" uritten a year before Petrarch's death, he aska "What 18 all History but Praise of Rowe."165 I w11 take this as the quinteasential atatement of the 165Quoted by Beryl Saalley In English Frlare and Antiquity (New York: Barnes and Noble, 1960), p. $2 \overline{92}$ 
function of Petrarch's historlcal 1maginatioa. The key word is "pralse" for lt reveale the pervesive historical rotanticiom with which Petrarch approached his subject. The phrase "historical 1megination" does not necessarily inply a romantic vision. Practical solutions can be offered if the world is seen realistically as vell as lasginatively. If this is to be, as Myron Gilmore polnts out, "History has to be more inltated than admired."166 Petrarch, however, Identified so completely with his Ideal of Rone that concrete applicatIons of Rosan precedents to fourteenth-century Italy escaped him. As ts evidenced in his works and deeds, from Africa and the Coronation to Cola and Charles IV, the appearance of a classical maner was all Important. In Friedrich Gundolf's terms the "classical gesture" was the panacea. It was as 1f, specifically, the revival of the crowaing of a poet laureate would usher in another age of epic poetry. The romantic flaw in this approach is steted to Petrarch by Charies IV who polftely but pointedly denied that having the title Emperor of the Romans would make his task any easier.

In order to set off Petrarch's romancic vision of history I shall contrast it to his wethodology. Clearly there is no reason to asaune that since Petrarch had many "humanist cools" at hand that be necessarily should have used them in a consistent manner.

166 Myron P. G11more, "The Renalssance Conceptions of the Lessons of History," in Pacets of the Renaissance, ed. by Willian H. Herkmeister, Harper Torchbooks (New York: Harper and Row, 1959), p. 90. 
Peter Burke, in his excellent essay The Renalssance Sense of the Past, offers three distlagutshing factors between Medieval and Renaissance histortcal perspective. It is a serse of anachronian, an abareness of fvidence, and an treerest in csusacton which defines the advarce of historical wethod in the Renalssarce. 167

In termat of theae ioolated coucepts. It is evident that Pekrarch cantot be called an historical innocent. His stzong curiousity about the Rosan past led his ever deeper into the literature, history, and letters left bentad by the ancients. Revelling in the glorious vords and deeds of the Romens, Petrarch edmits, "I gave miself wholly to Clcero. "168 Parrarch's sense of historical distance, critical use of sources, and concern with the power of indivldual personality grew out of his reed to "pralse" the Roman heritage. Any rethodologlcal advances over his predecessors were not directed tovard a transcendent hiscortcal standard. Petrarch? use of historical evidence developed out of a dence to provide the wost certain and convincing facts to bolorer his ideal.

Antiquity, for Petrarch, was an Ideal sociecy from which to gather the basc knowledge needed by men to achieve proper virtuousnews. Because history offered proven examples of superior morality, It was the duty of the bistorian to sift out and record with the fire of a great thetorician, the exampies men should follow.

167 Peter Burke, The Renaisgance Sease of the Past. p. 1. ${ }^{168}$ Quoted by Bishop In Petraxch and His World, p. 21; Seniles $X V I, 1$. 
Petrarch saw the past as qualitatively different frow the preseat. His sense of anachroniste was groumded ou the disstailartiy in the cultural content of the "anctent" and "zodern" ages. Livg and Clcero could not have any knowledge of Christianity. Perrarch's appreciation of this fact is seen in his pity for their birth in an "ill-fated" age. To be critical of thatr ignorance vould be an histortcal fallacy.

Petrarch'a sense of anachronism was closely connected with his awareness of evidence. It was because of the maig linguistic anachrontsms that Petrarch told Charles IV the "Caesarean privilege" was a forgery. 159 Petrarch's "asgociation" with Rome depended solely on the words of ancient authors. His fatilarity with classical Latin usage allowed hiw to establish the cultural context of the forgery. Petrarch never directly critlcized the theologieal incerpretation of history. His celebration of the personality is, however, an ieplicit compent on the medieval orlentation. We cannot attribute a cossclous eyclical theory to Petrarch bue his historlcal perspective ts not strictiy providential. The iaportance of the individual perscasilty in determining history is evidenced by The Lives of Iluserlous Men. Sciplo and Hanntbal, Cacsar and Pompey were not nere actors in historfcel drana. Responding to Individual abielors and goals, they laitiated action which lavolved the greatest civilizathons of the day. Petrarch's relstions to Cola, Chaxles IV, and Pope ${ }^{169}$ Burke, The Renatssance Sense of the Past, p. 31. 
Urban $V$ also auggest that men in the real world had the same potential to drect future events.

Petrarch's concern with the passage of time 18 the suprene factor in distingulshing his historical imagination fron the medieval. Peter Burke states, "It way be relevant that much medleval history was uritten by the monks, and that monks were professionally concerned, one wight asy, with the timeless." 170

An Indication of the necessary relation of history to the temporal 1. Petrarch's view of the law. Petrarch denied the ahlstorlcal medieval perception of 1 at so an abstract truth existing above time. DevelopIng In response to concrete needs, the lav had a history. Petrareh advocated a study of the origins of law and the founders of furiuprudence as a practical afd to the historical knowledge of both past and present. An obrezsion with the passage of tire confirms the essential romanticisa of Petrarch's historical outlook. "Tive" was not berely one of two abstract dimensions used to place man in the continuun of hietory. Petrarch did not belleve that human action ooved forward through an "objective" reailzy. The Triumph of Time reveals a destructive coswic force, personified to the extent that it actually takes reverge on himanity.

Bergin attributes a "cult of memory approaching the morbid" to Petrarch. 171 The overvhelning mewory of the "golden age" of antiquity wade Petrarch conscious of the worenent of time. This

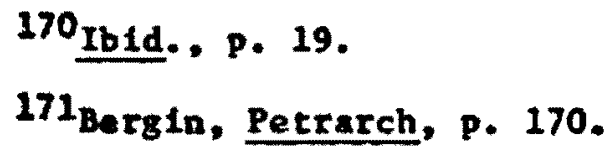


movement was negative and destructive precisely because it separated Petrarch from his truest friends. Tled to the "land of the living" Petrarch exereised his historical Imagination to bridge the gap of chronological time. In diselnguishing cultural from historical time Petrarch could escape the confines of his era and comunicate directly wth Livy and Cicero. Petrarch's "Letter to the Ancient" were both historically romantic and historlcally real. Fe wrote in the present tense, emphasizing the spiritual reality of the intellectual relation. Yet, since the letters are "sent" from the "land of the 1iving," they acknowledge a difference between the past and the present. The sense of anachronisn 18 ever present and a potgnant reminder of the dietinction between the real and the 1 deal.

It will now be necessary to 1 solate the histortcal sources out of which Petrarch's romancic wemories grew. In saying "What is all History but praise of Rome," Petrarch Intended to insplre an appreciation of the antique heritage in his contemorarles. In his critique of fourteenth-century society, "Rome," defined as a vague spiritual force, was Petrarch's main tool. Transcending both tize and fact, "Rowan civilizstion" Incorporated both Petrarch's positive view of the post and his negative response to the present.

Petrarch had a preconcelved notion of "Rcae" and the components of the "clasalcal heritage" long before he visited Itzly in 1337. This fision, founded on the Letin readings of his youth, would only grow broader in subsequent years. Virg1l, Livy, and Cicero were personifications of the Ronan spirtt. Petrarch percelved Rowe directly through their "eyes." The rulns of Rowe were only secondary evidences 
of a great civilization. More imediate vere the written words of anclent authors for it was through them that antiquity lived again in Petrarch'a rind.

There 1s no use in asking whether Petrarch's "Rome" was a republlc or an eapire, pagan or Chrlstian. Because Rome was a th, existing outside historical tiwe, it was both and neither. Just as Petrarch's Scipio and Caesar never existed in real life, Rosan civilizatica was a historico-mythicel state created for didactic enda. "Rame" was a romantic nemory rising from readings alone. The "monuments" of this epic age of great poets, philosophers, and milltary heroes, however, left a visible imprint on historfcal development. The "Antique Heritage" consisted of the words of classical authors passed on to posterity. In transmitting classical genius the words themselves carried a living body of wisdow useful to all ages.

As often as not, Petrarch defined the "Antique Heritage" in negative terws. It was everything that the aodern age was not. True poetry, spirituality, philosophy, and government were bezt described 1n coaparison. The present fad of bad poetry, the corruption of the Church and renoval of the Holy See to Avignon, Aribtotelianiam, and the perversion of the Holy Roman Baplre Into a territorial German state all syabolized a cultural degeneration. Because Petrarch's culture contained little of value, "Rowe" shone more brightly. It was by default, as it were, that historical Rome galned mythical qualitles, Everything Roman was to Petrarch necessarily "Irue," "Good," and "seautiful." 
The sense of distance from and longing for a lost era was a factor uncomaion in the medeval historical inagination. Petrarch, hovever, was not a constructive thlnker, offering no practical methods for remedying the current situation. Directing his sensual recollections to a bygone age, Petrarch refused to deal with social problems on a concrete level. His admonitions to Cols, Charles IV, and the popes focus on the past. Either out of frustration or an Inability to recogaize fourteenth-century realities, Petrarch advocated refoms that could only be gestures at changlag soefety. Since he had no grasp of what Rope or the Trecento really was, Petrarch refused to accept Cicero's "new" personallty as revealed in the Letters to Attlcus. Stallarly, he did not comprehend how Germany could be nore Important to Charles than Italy. Petrarch's historical awareness was limited on principle. Truch vas acceptable only if new facts colncided with his preconcelved bellefs. Petrarch would only admit that Cicero was not being true to himself and that Charles was no emperor of Eomans, only King of Bohewia.

Petrarch woze the same romantic "b11nders" when viewing the situation of the "Babylontan Captivity." His criticisms of Avignon were based on a spiritual tradition not on polftical realities. The popes could not survive anidst the baronial couflicts in Rome and that 18 why they noved to Avignon. Petrarch naively assumed that a spleitual transformation would result from a simple geographic relocation. Chaos would disappear and purity would reappear with the return of the Holy See to Rose. 
One strain of Petrarch's histortcal rowanticisw would be speclfically Incorporated into fifteenth-ceatury humalsa. It was the bellef in the power of the oritten word to effect real change. The "Classical Revival" necessitated the development of a rhetortcal culture. The initial assuaption was that antiquity could provide already perfect models for action which need only be copied. However, eloquence was the most powerful force behind action. The creative power of rhetoric lay, in fact, in adding fire to moral imperatives. The bellef In the capacity of eloquence to transform words into deeds 1s evident in the humanist identification of rhetcric and moral phllosophy. Raul Oskar Kristeller poluts out that the primary humanist critcism of nedieval philosophy was not directed at 1 ts content but 1ts form. "Their maln charges are against the bad Latin style of the medleval authors, againgt thelr ignorance of anclent history and literature, and against their concern for supposediy useless questions."172 Petrarch belleved eloquence was necessary to express wisdom. He accepted the classical dictun that the art of oratory embraced the wole realu of human knowledge, Including moral philosophy and history. What has been seen as a degeneration of philosophy into a purely gramatical concern may well have grown cut of Petrarch's blind adulation of Cicero's "golden tongue."

Petrarch's sense of his potential use to future historical development comes out of this optintstic fath in rhetoric. The

172Peui Oskar Rristeller, Renafssance Thought: The Classlc, Scholastic, and Humanist Strains, Harper Torchbooks (New York: Harper and Row, Publishers, Inc., 1961), p. 101. 
scholar's duty was to revive and pass on ancient visdom. The Coronation Oration shows Petrarch felt he had refolned the flow of history and could bring not empty words but the active spirte of anclent geniue to posterity. The prediction of Enalus in the Afrlcs also reflects Petrarch's beilef in the constructive power of words. Poetry, after al1, was the sediun through which "virtue" transcended death and reentered the cultural tradition.

Petrarch realized he was not a "man of action" but belleved he could have an equally great effect on history as a poet. In Sonnet XXXII Petrarch says,

If love ox deach rend we not asunder. If I can free we from by binding trap, The yarn I have for spinning, it may hap. Wi11 give the century a cause for wonder. The anctent and the new I plan to piunder And make two truths so neatly cverlap That--dare I say it?-msuch a mighty clap I'11 make that even in Rome you' 11 hear it thunder. 173

It 18 only with the dawn of a new age sympathetic to poets and scholars that thls synthesis can take place. The dedication of Africa to Posterity epitomizes Petrarch's attempt to transcend the present. Writing an epic modeled on the Virgilian tradition, Petrarch hoped his fane would be carried into the future on the Afrlca. Posterity, In the sense most often used by Petrarch, does not refer to a speetfic histcrical time. It 18 a romantic vision, a promise not unlike Heaven, that the virtue of the past w11 be sometime rewarded. Yet, like

${ }^{173}$ Francesco Petrarch, The Sonnets of Petrarch, ed, and trans. by Thowas G. Bergin (New York: Herltage Press, 1966), p. 38, $(1326-36)$. 
87

Petrarch's vision of Rome, Posterity was grounded in history. The present would pass away and Posterity would become an eternal present. In the words of the Triumph of Eternity "Future and Past, like hills. that hid our view, are levelled now."

Caught in the present Petrarch used his historical imagination to transport himself through el me in both directions. That he is et111 read not, in "Posterity," justifies hits faith in the lasting power of beautiful words. Petrarch's clair to imortality stands in Sonnet LXXXIII. "Only the poet" pure I mortal plan outwits the swift mortality of man."174

174 Ibid., p. 93, (1337-41). 


\section{BIBLIOGRAPHY}

Auerbach, Erich. Literary Language and its Public in Late Antigulty and In the Middle Ageg. New York: Pantheon Books, 1965.

Baron, Hans. "Cicero and the Civic Spirtt in the Middle Ages and Early Renaissance." Bulletin of the John Rylands Library, XXII (1938), 84-89.

- The Crists of the Early Italian Renalssance. Princeton, H. J.: Princeton University Press, 1966.

- "Franciscan Poverty and Civic Wealth in the Rise of Huanistic Thoughe." Speculum, XIII (January, 1938), 1-38.

- From Petrarch to Rruni: Studies in Humanistic and Political Literature. Chicago: University of Chicago Press, 1963.

- "Petrarch: Hts Inner Struggles and the Huanistlc Discoyery of Man." Florilegium Historlale: Issays presented to Wallaes R. Ferguson. Edired by J. G. Rowe and W. H. Stoct.dale. Toronte: University of Toronto Press, 1971.

Bayley, C. C. "Petrarch, Charles IV, and the 'Renavatio Imperi1." Speculum, XVII (July, 1942), 323-41.

Bergin, Trumas G. Petrarch. New York: Twayne Publishers, Inc., 1970.

Bernardo, Aldo S. Petrarch, Sclpio, and the Africa. Baltimore: Johns Hopkins Press, 1962.

- "Petrarch's Attitude toward Dante." Publications of the Modern Janguage Assoctation, LXX (June, 1955), 488-517.

B11lanovich, Giuseppe. "Petrarch and the Textual Tradition of Livy." Journal of the Harburg and Courzuld Iastitute, XIV (1951), 137-205.

B1shop, Maris. Petrarch and His World. London: Chatto and Windus, 1954.

Burke, Peter. The Renalssance Sense of the Past. London: Bdward Arnold, 1969. 
Col1sh, Marcia L. The Mrror of Language: A Study of the Medieval Theory of Knowledge. New Haven: Yale Uuiversity Press, 1968.

Cosenza, Mario Erail10. Francesco Petrarch and the Revolution of Cola di Rienzo. Chicago: University of Chicazo Press, 1913.

Dav18, Charles Till. Dante and the Idea of Rose. Oxford: C1arendon Pres8, 1957.

Perguson, Wallace K. Europe in Transtelon: 1300-1520. Boston: Houghton Mifiln Co., 1962.

Gilmore, Myron P. "The Renalsance Conceptions of the Lessons of History." Facets of the Renalssance. Edited by Willian H. Herkmelster. Harper Torchbooks. New York: Harper and Ron, Publishers, Inc., 1959.

Gundolf, Frledrich. The Mantle of Caegar. New York: Vanguard Press, 1928.

Holmes, George. The Florentine Enlightenment. New York: Pegasus, 1969.

Kr1steller, Paul Oskar. Renaissance Thoupht: The Classic, Scholastic and Humanist Strains. Harper Torchbooks. New York: Harper and Row, Publishers, Inc., 1961.

Mommen, Theodore E. "An Introduction to Petrarch's Sonnets and Soags." Medieval and Renalasance Studies. Edited by Eugene F. Rice. Ithica: Cornell University Press, 1959.

- "Petrarch's Conception of the Dark Ages." Medieval and Renalssance Studies. Edited by Eugene F. Rice. Ithica: Cornel1 University Press, 1959 .

- "The Sala Virorum IIIustrdum." Medieval and Renalssance Studies. Edited by Eugene F. Rice. Ithlca: Comell Unviersity Pres8, 1959.

Nolhac, Plerre de. Petrarch and the Anclent World. Edited by Lewis Einstein. Boston: D. B. Updike, 1907.

Petrarch, Francesco. "The Ascent of Mont Ventoux." The Renalssance Philosophy of Man. Edited by Ernst Cassirer, Paul Oskar Kristeller, and John Herman Randall, Jr. Chicago: University of Chicago Press, 1948. 
Struever, Nancy. The Language of History in the Fenajssance. Princeton, N. J.: Princeton University Press, 1970.

Tacam, Edward H. R. Frsucesco Petrarca. London: She1don Press, 1926.

Thomson, S. Harrison. Europe in Renaissance and Reformation. Nev York: Harcourt, Brace, and Horld, Irc., 1963.

Trinkhaus, Charles. In Our Image and Likeness: Humanity and Divintty in Itallan Humanist Thought. vol. $I$. London: Constable and Co. 1970.

U11man, Berthold L. Studies in the Itallan Renalssance. Rome: Edizioni di Storia e Letteratura, 1955.

Waley, Dante1, Later Medleval Europe. New York: Barnes and Noble, Inc., 1964.

We188, Roberto. The Renaissance Discovery of Classical Aatiquity. New York: Humanities Press, 1969.

Whitfleld, John H. Petrarch and the Renascence. Oxford: Baall Blackwe11, $194 \overline{3}$.

Wt1kins, Ernest Hatch. The Life of Petrarch. Chicago: University of Chicago Press, 1961.

- Perrarch's Correspondence. Padua: Editrice Antenore, 1960.

- Persarch's Eight Years in Milan. Cambridge, Mass.: The Medieval Academy of America, 1958.

- Petrarch's Later Years. Cambridge, Mass.: The Hedleval

Academy of America, 1959.

- Studies in the Life and Work of Petrarch. Cambridge, Mass.:

The Yedieval Academy of America, 1955.

- "Works that Petrarch Thought of Wrizing." Speculum, XXXV (October, 1960), 563-71.

Wrigley, John E. "A Papal Secret Known to Petrarch." Speculum, XXXIX (October, 1964), 613-34.

21merman, To C. Price. "Confessions and Autoblography in the Early Renaissance." Renaissance: Studies in Honor of Hans Baron. Bdited by Anthony liulho and John A. Tedeschl. Deklab: Northern Illinols Press, 1971. 